Check for updates

Cite this: RSC Adv., 2017, 7, 29395

\title{
Fermentation factors influencing the production of bacteriocins by lactic acid bacteria: a review
}

Received 2nd October 2016 Accepted 27th March 2017

DOI: $10.1039 / c 6 r a 24579 j$

rsc.li/rsc-advances

\author{
Sahar Abbasiliasi, (DD a Joo Shun Tan, ${ }^{c}$ Tengku Azmi Tengku Ibrahim, ${ }^{\text {dg }}$ \\ Fatemeh Bashokouh, ${ }^{d}$ Nagasundara Ramanan Ramakrishnan, ${ }^{\mathrm{e}}$ Shuhaimi Mustafa ${ }^{\mathrm{ab}}$ \\ and Arbakariya B. Ariff ${ }^{\star b f}$
}

Lactic acid bacteria (LAB) are of major interest in the food industry primarily by virtue of their biopreservative properties. LAB have ability to produce various types of antimicrobial compounds, the most important being bacteriocins. Bacteriocins and bacteriocin-producing cultures have the potential to increase the shelf-life of foods and contribute towards decreasing the incidence of food-borne diseases. In this respect, food preservation through in situ production of bacteriocins by LAB introduced into the food system would be the most logical approach. However, there is a need to understand the relationship between bacterial growth and bacteriocin production in various types of food system. Bacteriocin production by LAB is dependent on a number of factors such as the types of carbon and nitrogen sources and their concentrations in the media formulation. Other factors which need to be considered are the culture conditions which include $\mathrm{pH}$, temperature and aeration which greatly influence the cultivation performance of bacteriocins producing LAB. Economic aspects pertaining to the optimization of fermentation process for the enhancement of bacteriocin production should also be given due considerations. Failure to acknowledge or recognize this hidden economic element would be a substantial financial loss to the industry especially from the point of view that the product is costly and highly sought after. Thus, the fermentation factors which influence the production of bacteriocins by $L A B$ and the approaches to improve the production not only in term of yield and productivity but also in term of economic and regulation are reviewed in this paper.

\section{Introduction}

The demand for foods with minimum processing or foods without chemical preservatives is fast gaining momentum in view of increasing concerns on health. ${ }^{1}$ It is well known that various pathogenic and spoilage microorganisms, already present in foods could survive and multiply when there is minimal processing and/or in the absence of preservatives. In

\footnotetext{
${ }^{a}$ Department of Microbiology, Faculty of Biotechnology and Biomolecular Sciences, Universiti Putra Malaysia, 43400 UPM Serdang, Selangor, Malaysia. E-mail: arbarif@upm.edu.my; Fax: +60 3 89467593; Tel: +60 389467591

${ }^{b}$ Bioprocessing and Biomanufacturing Research Centre, Faculty of Biotechnology and Biomolecular Sciences, Universiti Putra Malaysia, 43400 UPM Serdang, Selangor, Malaysia

'Bioprocess Technology, School of Industrial Technology, Universiti Sains Malaysia, 11800 Penang, Malaysia

${ }^{d}$ Pharmacology discipline, Faculty of medicine, UiTM, 47000 Sungai Buloh, Selangor Darul Ehsan, Malaysia

${ }^{e}$ School of Engineering, Advanced Engineering Platform, Monash University Malaysia, Jalan Lagoon Selatan, 47500 Bandar Sunway, Selangor, Malaysia

${ }^{f}$ Department of Bioprocess Technology, Faculty of Biotechnology and Biomolecular Sciences, Universiti Putra Malaysia, 43400 UPM Serdang, Selangor, Malaysia

${ }^{g}$ Department of Veterinary Preclinical Sciences, Faculty of Veterinary Medicine, Universiti Putra Malaysia, 43400 UPM Serdang, Selangor, Malaysia
}

this respect natural biopreservatives such as bacteriocins which are non-detrimental to human health, have surfaced as an alternative to processing and the use of chemical preservatives in foods.

Bacteriocins are extracellularly released and ribosomally synthesized low molecule mass peptides or proteins with bactericidal or bacteriostatic mode of action, in particular against a wide range of mostly closely related Gram-positive bacteria and even against food-borne pathogens, but the producer cells are immune to their own bacteriocins. ${ }^{2}$ The use of bacteriocins or bacteriocins producing lactic acid bacteria (LAB) with a wide range of antimicrobial activity could improve safety, control the fermentation microflora, accelerated maturation and increase the shelf life of the products, inhibit the growth of certain pathogenic bacteria during the fermentation and ripening periods, which overall improve the safety aspects of these products. ${ }^{3,4}$

Bacteriocins are known to be produced by many Grampositive and Gram-negative microorganisms. However bacteriocins produced by Gram-positive microorganisms such as LAB are preferred principally attributed to their preservative properties especially in the food industry. This preference is also partly due to their broader inhibitory spectrum compared to 
that of Gram negative microorganisms. Applications of bacteriocins in the food industry had markedly increased with increasing concern in the use of chemical preservatives (e.g. nitrites) which are detrimental to human health. Bacteriocins are also generally regarded as safe (GRAS) substances which could be used as food additives or natural preservatives.

The search for bacteriocins with the ability to inhibit the growth of bacterial pathogens such as L. monocytogenes is of particular interest in the food industry. LAB could inhibit the growth of the pathogens through the activity of bacteriocins synthesized by these microorganisms. Many strains of LAB have been referred to the European Food Safety Authority (EFSA) for safety assessment without raising any safety concerns. Consequently, they have been included in the QPS (Qualified Presumption of Safety) list authorized for use in the food and feed chain within the European Union. The same applies to the US, where they display the GRAS status assigned by the U.S. Food and Drug Administration (FDA). ${ }^{5}$ Thus the identification and characterization of bacteriocin-producing LAB has grown rapidly in the last decade. ${ }^{6}$ Bacteriocins had demonstrated remarkable diversity in their effects on numerous bacterial species. Bacteriocins produces by LAB are considered as safe natural biopreservatives in view of the fact that proteases in the gastrointestinal tract could easily degrade it, ${ }^{7}$ hence harmless to the human body and surrounding environment. ${ }^{89}$ From the point of view of the industry there is a need for an inexpensive, large scale bacteriocin production suitable for various food applications. ${ }^{\mathbf{1 0 , 1 1}}$ Bacteriocin utilization as a preservative could be in two ways; (i) incorporation of bacteriocin-producingstarter culture, and the incorporation of bacteriocin extract or in the pure form. The latter would require an optimal and efficient fermentation which is heavily dependent on factors which are both specific and multiple for maximum production of bacteriocin ${ }^{\mathbf{1 2}}$ with low cost and efficient extraction and purification methods. From the commercial standpoint, the priority will always be the production of the highest quality, at the lowest cost and in the shortest possible time.

Bacteriocin production by LAB usually follows primary metabolite growth-associated kinetics which occurs during the exponential growth phase and ceases once stationary phase is reached. ${ }^{13}$ This implies that bacteriocin production is dependent on the bacterial total biomass. However, a high cell yield does not necessarily results in a high bacteriocin activity since the latter may be limited by a low specific bacteriocin production, i.e. a low bacteriocin production per gram of cells. ${ }^{14}$ Thus there exist a rather complex relationship between environmental conditions and bacteriocin production. ${ }^{15}$ Relationship between bacteriocin production and growth also depend upon the strain used. In some cases a correlation exist between peptide and biomass production, ${ }^{\mathbf{1 6}}$ while in other cases bacteriocin production only starts when stationary phase is reached. ${ }^{17}$ The yield per unit biomass is influenced by several factor which include the producing strain, medium composition (carbohydrate and nitrogen sources, cations, and etc.), fermentation conditions $(\mathrm{pH}$, temperature, agitation and aeration) as well and mode of fermentation (batch, fed-batch and continuous fermentations). ${ }^{18}$ Unfavorable conditions referred to as stress factors are also known to markedly affect bacteriocin production. ${ }^{19}$

Optimization of fermentation conditions is a complex approach but critically essential for high performance bacteriocin production at commercial scale. In order to develop high performance fermentation process, a better understanding of the influencing factors that affect growth of bacteriocin-producing $\mathrm{LAB}$ and their ability to produce bacteriocin is essential. The influencing factors may be strain dependent and could vary with different types of bacteriocin. The effects of two important factors - medium compositions and cultivation conditions, which influence bacteriocin production during fermentation of various $\mathrm{LAB}$ strains ${ }^{20}$ are discussed in this review.

\section{Effect of medium composition}

\section{Complex media}

Abundant selection of complex media (CM) for the cultivation of LAB are available in today's market. These include the de man rogosa and sharpe (MRS), brain heart infusion (BHI), NaLa (sodium lactate), M17 and trypticase soy broth yeast extract (TSBYE). ${ }^{21}$ The complex basal media which are commonly used in the cultivation of LAB for bacteriocin production are summarized in Table 1. Most media are designed for specific strains, e.g. M17 for lactococci and MRS for lactobacilli. These media promote exuberant growth and enhance bacteriocin synthesis. However, the use of these media could be uneconomical for industrial application due to their high cost, specific preparation steps and long incubation time. Cost is primarily due to the expensive nitrogen sources such as beef extract, yeast extract and peptone. ${ }^{22}$ There are also unutilized proteins at the end of fermentation which could affect the efficiency of the subsequence downstream processing for bacteriocin extraction and purification.

Being the growth media for a broad range of bacteria, these complex media are also not optimal in composition and concentration for use in specific strains for bacteriocin production processes. These limitations include the availability of certain essential molecules which are required for cell metabolism, the production of organic acids that cause a reduction in culture $\mathrm{pH}$ resulting in antimicrobial effects, lack of nutrients during exponential growth, lack of essential minerals such as $\mathrm{Fe}^{2+}$ and $\mathrm{Ca}^{2+}$, as well as lack in different carbon sources which are required or preferred by some LAB strains. These limitations are due to the fact that LAB strains have a wide range of variations in their growth requirements and that cause much of complexity forming general growth media for LAB. On the other hand, low nutrient concentrations may cause fast depletion in the essential nutrient which may negatively affect growth whereas high nutrient concentration such as salts could also negatively affect growth or could be insoluble in water. ${ }^{23}$ Based on the above information, optimization of medium formulation or compound is required for improvement of bacteriocin production.

In view of the fact that bacteriocin production by LAB is growth-associated, it can be suggested that its production could be improved with the improvement of cell growth through the 


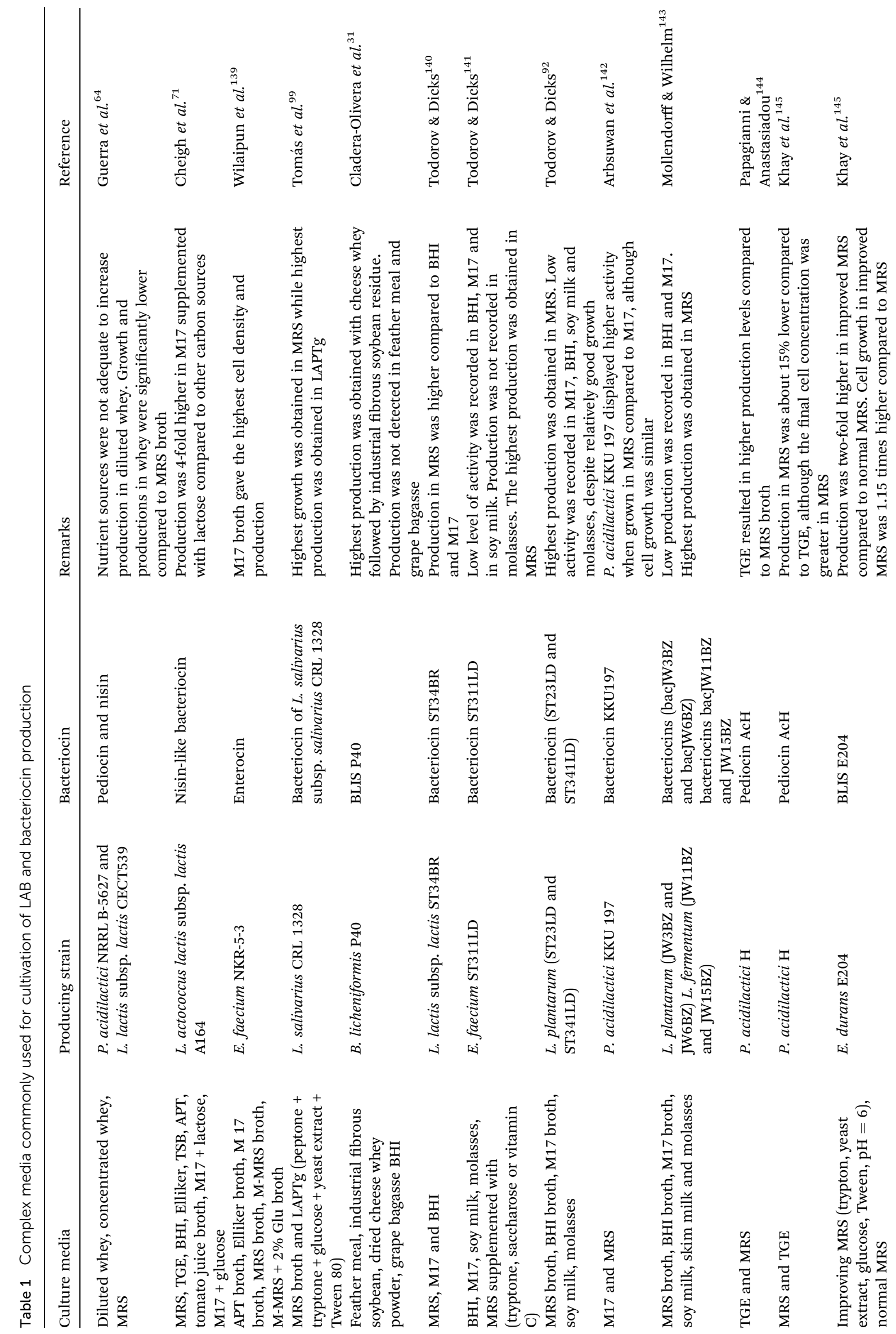


optimization of growth medium formulation such as carbon/ nitrogen ratio. This is supported by a report that the amount of carbon (glucose) and nitrogen source greatly influenced the bacteriocin synthesis during the growth cycle of $L$. mesenteroides L124 and L. curvatus L442. ${ }^{24}$ Another study showed that the optimization of medium formulation based on CM medium was successfully applied to increase the volumetric bacteriocin activity by $L$. lactis by two-fold. ${ }^{21}$ Medium optimization is not only important for enhancing bacteriocin production but it is also an important factor in terms of cost reduction. Culture medium could account for up to $30 \%$ of the total production cost in commercial fermentations. ${ }^{25}$

Optimization of formulation of growth medium is one of the key factors that need to be considered in the enhancement of any fermentation processes. Medium formulation for industrial scale fermentations should fulfill a number of criteria: it should be cost-effective, high product yield, short fermentation time and ease of downstream purification processes. ${ }^{26}$ However, the medium that gives the highest product yield may not in most cases be the most cost-effective. Choice of the preferred medium is therefore dependent on the situation and in most cases a trade-off between the different factors. Formulation of medium is not only aimed at improvement of bacteriocin production but also to stabilize its production. Medium components such as sodium chloride ( $\mathrm{NaCl})$, ethanol and high carbon source concentrations have been used to stabilize bacteriocin production. ${ }^{20}$ Medium $\mathrm{pH}$ has also been shown to significantly affect bacteriocin stability. ${ }^{27}$

Some medium components are used to induce stressful environment that could enhance bacteriocin production. This is brought about by either stabilizing the bacteriocin or by preventing the aggregation of bacteriocin molecules. $\mathrm{NaCl}$ and ethanol are two components that have the above-mentioned effects but with variable results. The presence of $\mathrm{NaCl}$ and ethanol was inhibitory for the production of some bacteriocins while stimulatory in others. ${ }^{28}$ Verluyten et al. ${ }^{29}$ reported that stress conditions due to nutrient limitation also could stimulate curvacin A production by L. curvatus LTH 1174.

Sugars, vitamins and nitrogen sources could be added to the culture medium as supplements to maximize bacteriocin production. Under normal circumstances there is usually an improvement of bacterial growth by the addition of supplements in the medium. However oversupply could lead to the inhibition of both bacterial growth and bacteriocin production. Alternatively the best-adapted culture medium could be formulated for maximum bacteriocin production. $\mathrm{LAB}$ is fastidious nutritional requirement microorganism. The fastidious characteristics of LAB could influence on nutritional requirements and metabolic capacity. In addition, fastidious nutritional requirements may also limit the ability to optimize and control the metabolic activities of LAB. ${ }^{23}$

The medium rich in yeast extract and protein hydrolysates is required for growth of $\mathrm{LAB}$ and good bacteriocin production. Good cell growth and bacteriocin production are complimentary to one another. ${ }^{30}$ However, high bacteriocin production need not necessarily depend on optimal cell growth. ${ }^{31,32}$ Although it has been generally accepted that bacteriocin production requires a complex medium, ${ }^{33}$ relatively simple medium could also be used for high production of bacteriocin. Many studies have determined the nutritional requirements of various bacterial strains in a completely defined medium ${ }^{34-37}$ but only very limited number of bacteriocins have been produced using a defined medium. ${ }^{38}$ In general, a semisynthetic media containing complex peptidic sources such as MRS, Tryptone glucose yeast extract (TGYE) or all purpose tween (APT) are required for bacteriocin production.

\section{Agriculture, food and industrial wastes}

The high cost of protein sources invariably poses a major problem with respect to application of specific technology for commercial applications. At the same time waste products from the food industry could be an environmental problem due to their high biochemical oxygen demand (BOD). Hence the incorporation of protein-rich food wastes in the culture media for the production of bacteriocin using $\mathrm{LAB}$ could play a major role towards solving the waste disposal problem while at the same time a techno-economically viable approach could be adopted for the production of bacteriocin on a commercial scale. ${ }^{39}$

The commercial media such as ATP, MRS and TGYE which are the common media for the production of bacteriocins and their metabolites by LAB are characterized by their components. These media, normally rich in salts and proteins varies in concentration and diversity of origin. These media are expensive and not balanced in term of $\mathrm{C} / \mathrm{N}$ ratio and other components. Thus, they are not suitable for industrial applications and may not support the production of the target bacteriocin. Since the $\mathrm{C} / \mathrm{N}$ ratio is not balanced, removal of the unconsumed protein materials which still remain in the culture at the end of fermentation is still a problem in the discharge of the liquid waste and at the same time hinder the purification of the bacteriocins from the culture broth. ${ }^{40}$

The use of low-cost protein fractions will bring about a cost reduction in large-scale production processes. The use of food waste generated by the processing of resources from marine origin to obtain the protein fractions will enable a close productive cycle: recycling of a pollutant waste and obtaining products (bacteriocins) with high added value useful for preservation of foodstuffs. ${ }^{41}$

Inexpensive medium for bacteriocin production by $\mathrm{LAB}$ could be formulated using industrial waste or by-products such as molasses, soy, hydrolysed wheat flour, cheese whey and corn steep liquor (CSL). ${ }^{26,42,43}$ A number of criteria should be considered when opting to use industrial waste in the formulation of fermentation medium. These include the carbon or nitrogen content, price, availability and level of impurities. Research conducted on the use various wastes in medium formulation for bacteriocins production are summarized in Table 2. Food-based industrial by-product media rich in carbon and/or nitrogen with reduced cost have been used for bacteriocin production by LAB with reasonable success. ${ }^{31}$ In spite of the high level of impurities but being of food origin these lowcost media have made bacteriocins production most appropriate for application in the food industry. 
Table 2 The use of various wastes in medium formulation for production of bacteriocins by $\mathrm{LAB}^{a}$

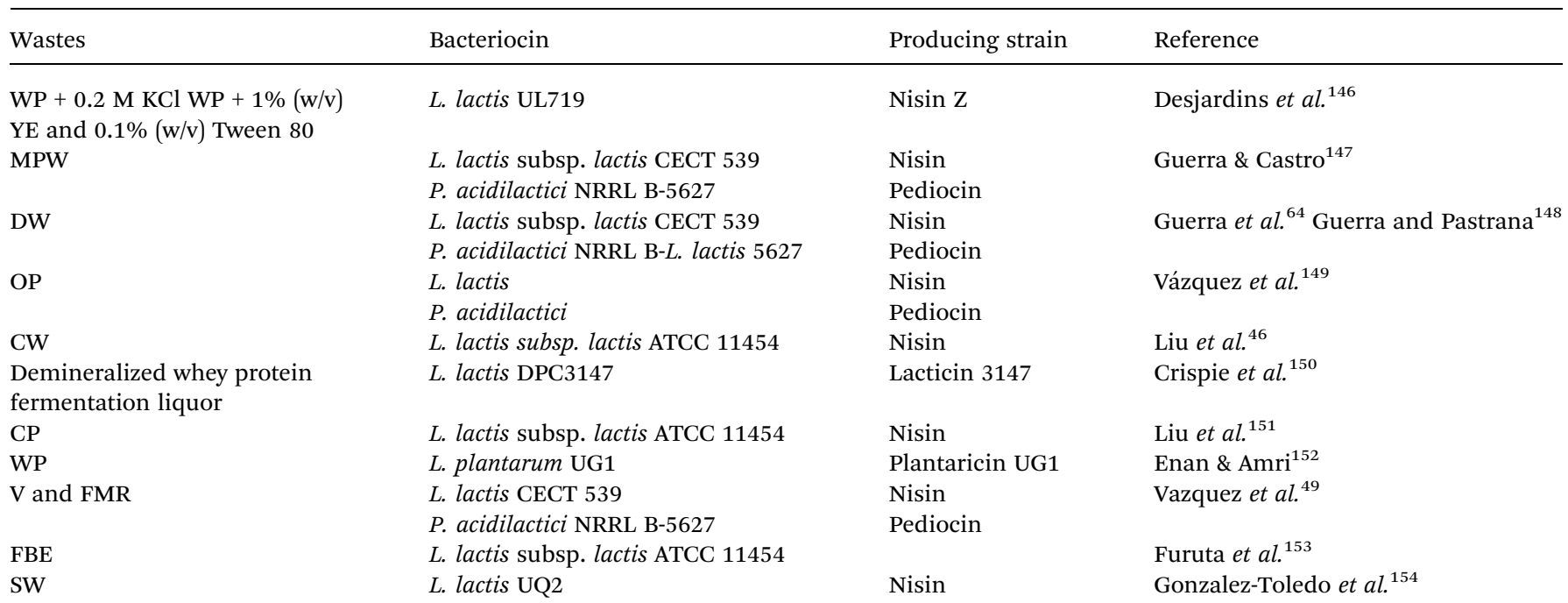

${ }^{a}$ WP: whey permeate; DW: deproteinized whey; YE: yeast extract; MPW: mussel-processing waste; TGE: tryptone/glucose extract; OP: octopus peptone; CP: cull potatoes V V \& FMR: visceral and fish muscle residues; CDS: condensed distillers soluble; FBE: fermented barley extract; SE: sweet whey.

Whey is a by-product of the dairy industry and contains rich nutrients such as lactose, soluble proteins and minerals salts. Unfortunately whey and its nutritional qualities have traditionally been treated as waste and represent an important disposal and pollution issue because of its high biological and BOD. Consequently, it is of interest to use this by-product as a fermentation substrate for the production of value-added products. ${ }^{44}$ Substantially high nisin activity was obtained after $9 \mathrm{~h}$ batch fermentation supplemented with whey. ${ }^{45}$ The use of a mixed culture of L. lactis and Saccharomyces cerevisiae to wheybased medium to stimulate the production of nisin have been reported. ${ }^{46}$ Cheese whey has also been successfully used for bacteriocin production by several LAB strains. ${ }^{47}$ Potatoes juice could be used as alternative substrate for $P$. acidilactici, $P$. pentosaceus, and L. sakei cultivation aimed at the reduction of microbiological contaminations in sausages. ${ }^{3}$ Subsequently, rye wholemeal has also been used as a substrate for the production of bacteriocin by L. sakei KTU05-6. ${ }^{48}$

The utilization of waste from the slaughter house for bacteriocin production appears to be another attractive option to solve the environmental problem. The residues of animals generated from meat industries, trout, swordfish, tuna or cephalopod wastes allow the simple, rapid preparation of protein hydrolysates or autohydrolysates which are suitable for the formulation of medium for LAB fermentation. Different peptones obtained from the fish viscera and muscle residues promote growth of LAB for the production of nisin and pediocin. ${ }^{49}$

\section{Role of carbon and nitrogen in LAB cultivation}

In fermentation, carbon and nitrogen sources are required for both growth and product formation. The characteristic features and nature of carbon and nitrogen play a major role in microorganism metabolism..$^{50}$ Nitrogen limitation phenomenon would switch to a carbon limitation phenomenon when there is an increment of nitrogen source concentration while the carbon source concentration is maintained. This could be explained by the fact that the carbon source is readily used up within a shorter period at higher nitrogen concentration and becomes limited in subsequent fermentation stages, suggesting that the yield of biomass would decrease with increasing nitrogen concentration. Nitrogen in one form or another is required for all processes involving biological growth especially with reference to synthesis of cellular protein and nucleic acid production. During fermentation, appropriate nitrogen supplementation is required by the microflora for its metabolism.

\section{Types and concentrations of carbon source}

The effect of carbon sources on the production of antimicrobial substances by various LAB strains are summarized in Table 3. By virtue of its size and rapid uptake, glucose is the main carbon source for all microorganisms which are rapidly utilized for energy conversion. ${ }^{15}$ Glucose is the preferred carbon source to stimulate bacteriocin production, in which, most researchers had demonstrated high bacteriocins yield in association with the presence of glucose in growth media and not other monosaccharide's. ${ }^{51}$ High yield of bacteriocins production in some LAB strains is associated with the inclusion of other sugars to growth medium rather than the use of glucose alone as they may have a complex enzymatic system that allow them to use other carbohydrates. This has been demonstrated in E. faecium which showed variable sugar utilization compared to glucose for bacteriocin production. Similar effect of sucrose and lactose are also confirmed for nisin production by L. lactis subsp. lactis. $^{52}$

Several LAB strains such as L. lactis $^{53}$ and S. pyogenes ${ }^{54}$ appear to use glucose preferentially for nisin $\mathrm{Z}$ and streptococcin SA- 


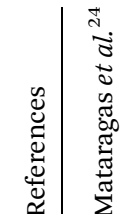

苛

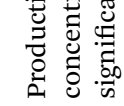

苑

.$\Xi \frac{2}{3}$

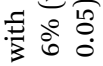

당

त्ञ

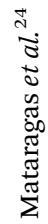

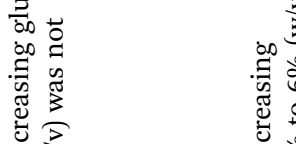

일

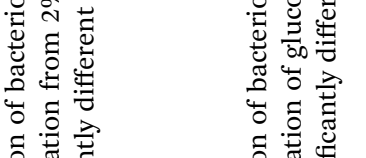

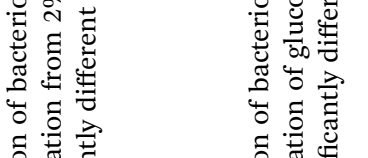

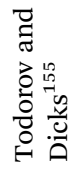

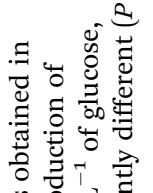

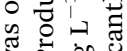

3 का के

.

글

$\Xi$ on

०ूำ

可 $\Xi$

उ 35

若目:

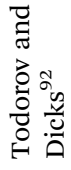

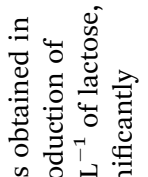

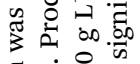

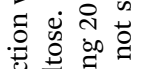

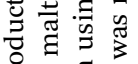

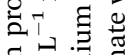

乎 कo

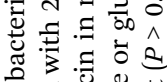

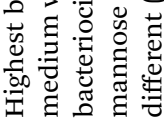

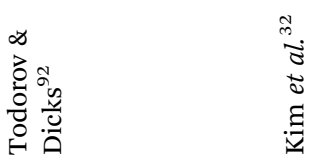

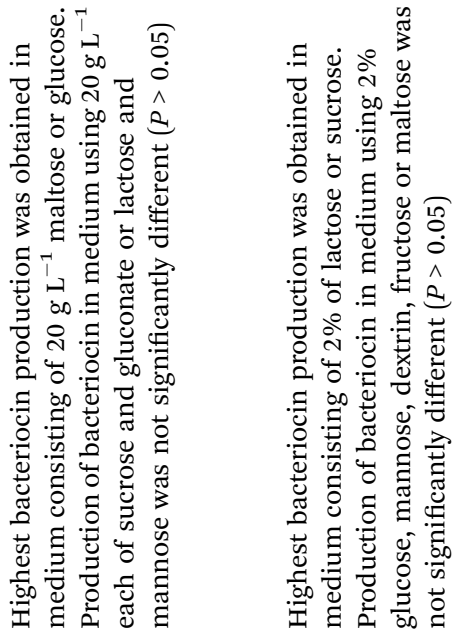

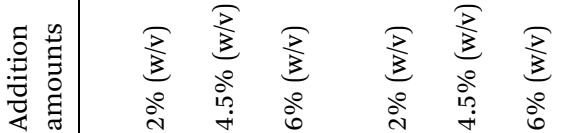

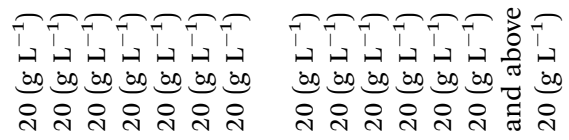

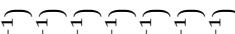

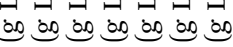

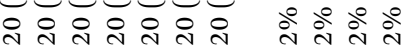

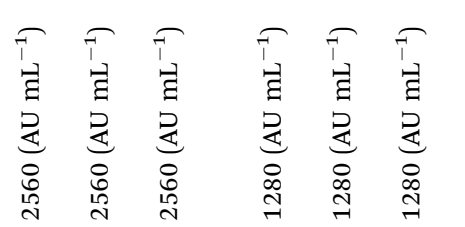

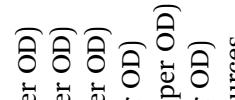

ิิㅇิㅇิㅇ

ชิ

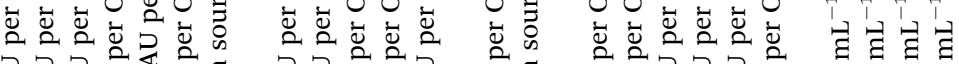

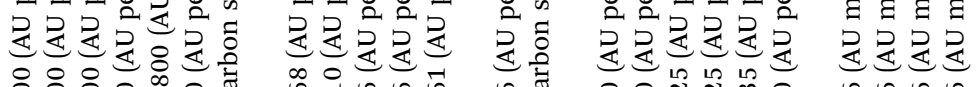

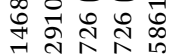

ำ

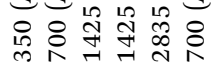

늑 뉵 육

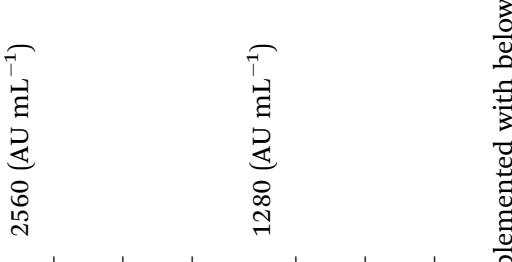

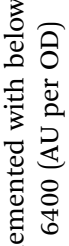

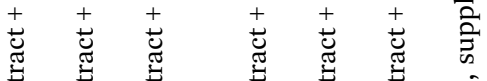

章

荧 0

范

西

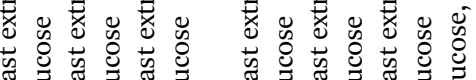

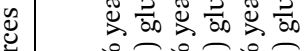

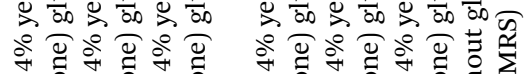

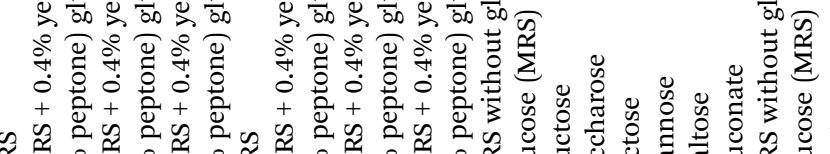

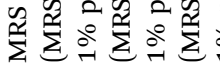

\section{$+\frac{1}{+}++\infty$}

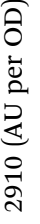

के

苞

妾

玄

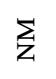

$\sum$

玄

玄 


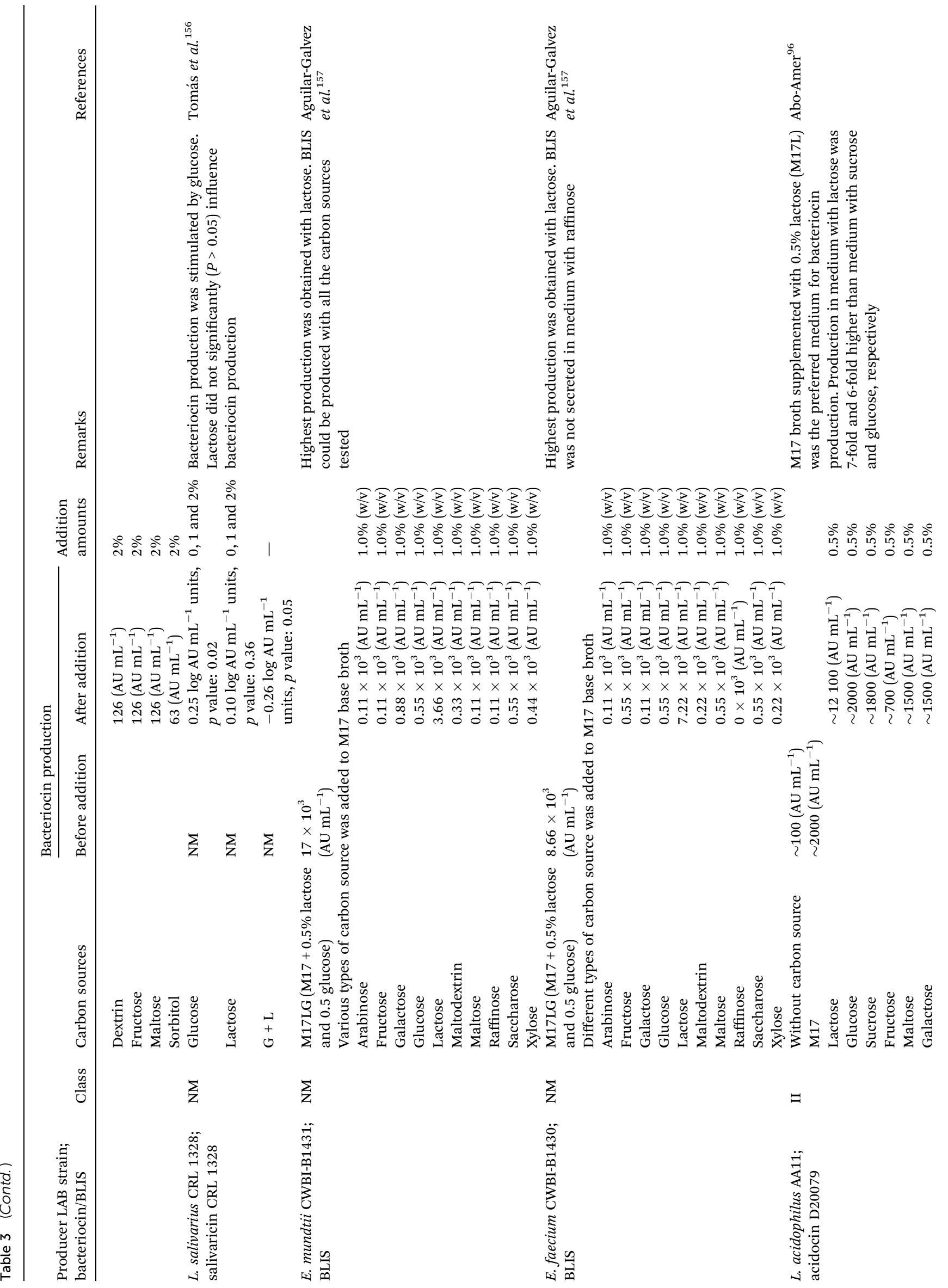




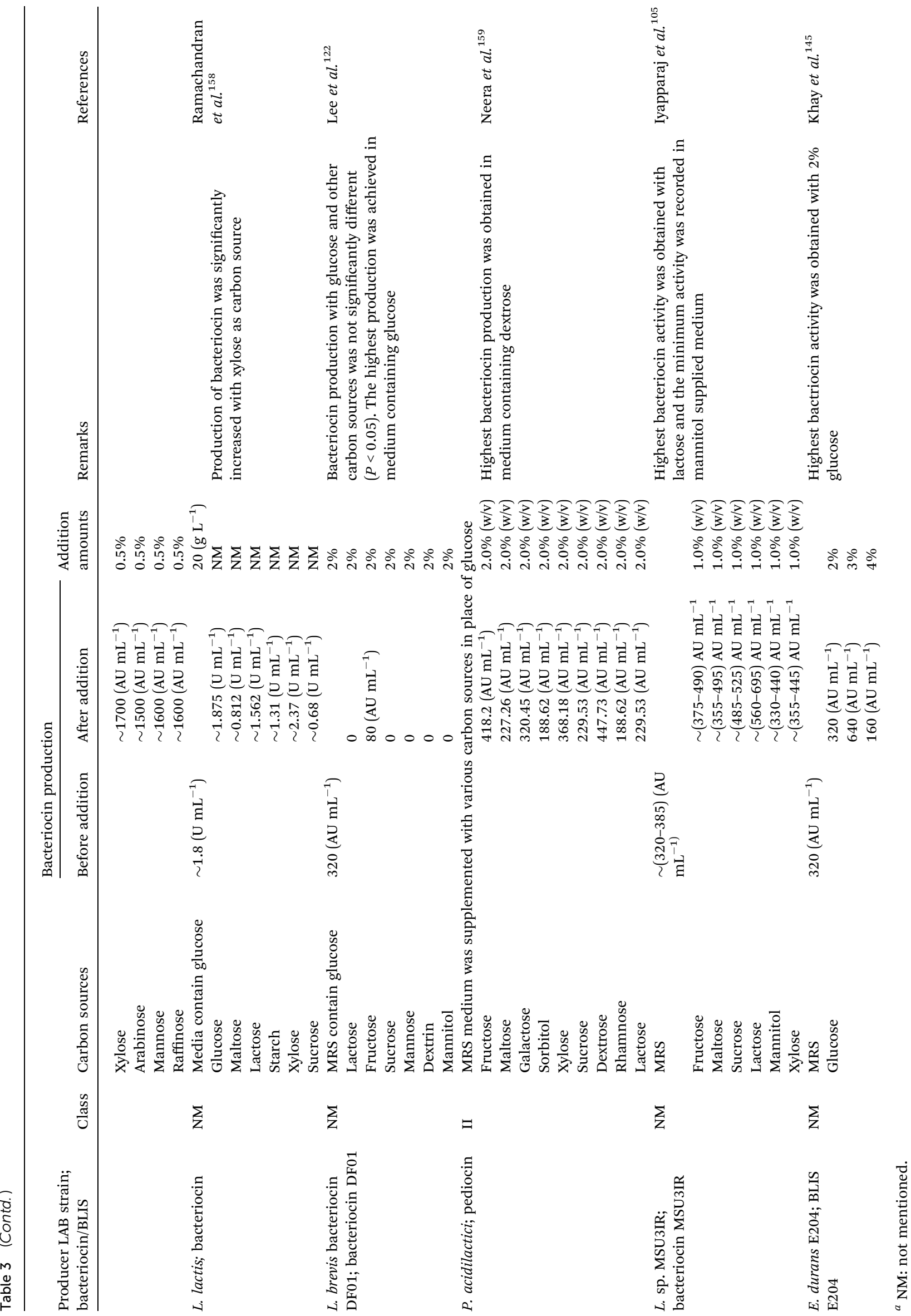


FF22 production, respectively. In L. lactis, glucose supports higher specific growth rates, faster substrate consumption and greater product formation compared to other carbon sources. ${ }^{55}$ Papagianni et al. ${ }^{56}$ reported a direct relationship between nisin production and the rate of glucose consumption by L $_{\text {lactis. }}{ }^{57}$ demonstrated that ruminal $S$. bovis uses glucose and sucrose preferentially to maltose and cellobiose and the utilization of these sugars was later shown to be regulated by specific phosphotransferase transport systems (PTS). ${ }^{58}$ However, Russell ${ }^{59}$ verified that glucose PTS could not account for the glucose consumption rates of rapidly growing cultures and a low-affinity facilitated diffusion mechanism was responsible for glucose transport at high substrate concentrations.

Starch has a negative effect on bacteriocin production which could be due to the attachment of bacterial cells to the surface of starch molecules which could cease utilization of the latter. ${ }^{60}$ Most bacteria are able to ferment mono- and di-saccharides and only a limited number possess the ability to ferment complex carbohydrates such as starch. Amylolytic LAB have the ability to secrete amylase which hydrolyse starch to fermentable sugars and these type of $\mathrm{LAB}$ have been used in simultaneous saccharification and fermentation processes. ${ }^{61}$ High molecular weight carbon and energy sources are broken down into smaller molecules by microorganism to be converted into amino acids, nucleotides, vitamins, carbohydrates and fatty acid to build these basic materials into proteins, coenzymes, nucleic acids, micropeptides, polysaccharides and lipids used for growth. ${ }^{62}$ Some bacteria are not able to ferment complex carbon sources, hence it is necessary to have a pre-treatment step where the sugars are hydrolysed into fermentable sugars. Hydrolysis can be achieved by either adding commercial enzymes such as glucoamylase to the broth or by using heat treatment at low pH. ${ }^{61}$ The problem with such treatments is the extra cost and complexity involved in the production process which render the procedure less favorable from both economical and production point of view. The ability of LAB to metabolize different carbon sources is based on the specific activities of the enzymes involved in carbohydrate degradation. In many cases, the addition of sugars lead to decrease in bacteriocin production which can be explained with the unfavorable conditions for growth and to some extent with the osmotic stress leading to decreased in growth rate. ${ }^{63}$ Osmotic stress, which increases the energy demand, apparently reduces the maximum secretion of bacteriocin, indicating that the energy is required in excess for the synthesis.

Production of bacteriocin is also influenced by the concentrations of carbon source. ${ }^{\mathbf{6 4 , 6 5}}$ Bacteriocin production is increased with increasing glucose concentration up to certain level. However, bacteriocin production is not stimulated at high glucose concentration due to the saturation of glucose transport inside the cells. In batch fermentation of $L$. lactis nisin production is inhibited at high glucose concentration $\left(25 \mathrm{~g} \mathrm{~L}^{-1}\right)$ due to a decrease in the rate of glucose uptake as reported. ${ }^{56}$ Pattnaik et $a{ }^{6}{ }^{66}$ also reported a decrease in bacteriocin production by $B$. licheniformis 26L-10/3RA at high glucose concentrations and hypothesized that this inhibition was caused by catabolite repression.

\section{Types and concentrations of nitrogen source}

The effect of nitrogen sources on the production of antimicrobial substances by various LAB strains are summarized in Table 4. In most cases the presence of a nitrogen source is crucial for bacteriocin production. Nitrogen source used as supplements include yeast extract, beef extract, peptone, malt sprouts and soybean. ${ }^{27}$ The response of microorganism to different concentrations of nitrogen depends largely on the type of nitrogen sources. Some microorganisms are not capable of synthesizing organic nitrogen compounds from the readily available nutrient in the media. Hence, this microorganisms especially those with complex nutritional requirement would need essential growth factors. These are in the form of essential nutrients which are necessary for viz. synthesis of nucleic acid which require purines and pyrimidines, synthesis of proteins which require amino acids and vitamins which are required as coenzymes and functional groups of certain enzymes. Instead of metabolizing the growth factors as a source of carbon or energy they are taken up by the cells and utilized to perform specific roles in metabolism. Catabolism of amino acid is known to have the capability of providing energy in an environment with limited nutrients. In terms of the catabolic pathways, the role of amino acids in LAB is not fully understood. Some LAB, through the arginine deiminase (ADI) pathway is known to produce extra energy by degrading arginine to citrulline, ornithine and ammonium. Although organic nitrogen is a complex nitrogen source made up of peptides and free amino acids, it is taken up directly from the medium by the cells. Hence this complex nitrogen source is incorporated into protein. Alternatively it is transformed into other cellular nitrogenous constituents. ${ }^{67}$ By contrast the cell spends more energy and time in synthesizing amino acids for protein synthesis from inorganic nitrogen sources..$^{68,69}$

Organic nitrogen sources such as peptone, beef extract, and yeast extract are commonly used to support good growth of $\mathrm{LAB}^{70}$ An organic nitrogen source, especially yeast extract, is considered to be of vital importance by virtue of its stimulatory effect on microbial cell growth. Yeast extract is the water soluble components of yeast cells made up primarily of amino acids, peptides, carbohydrates and salts. The excellent stimulation for growth is attributed to the presence of a high number of growth factors in the yeast extract compared to any other protein hydrolysates prepared by enzymatic hydrolysis. ${ }^{71}$ The amino acids or peptides in yeast extract could act as inducer or precursor for bacteriocin synthesis by LAB. The use of yeast extract which is rich in vitamins, minerals, amino acids and other easily consumable nitrogen sources, is not economical in a large scale fermentation process due to relatively high cost of this nitrogen source. The principal nutrients in the yeast extracts are purine and pyrimidine bases and group B vitamins. $^{72}$

Peptone is another major organic nitrogen source widely used in microbiological media. Peptone is defined as watersoluble, non-heat coagulable protein hydrolysates which contain a mixture of peptides, proteoses and free amino acids. ${ }^{73}$ The media recommended for the cultivation of LAB are those 


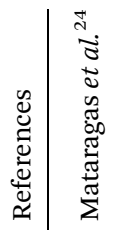

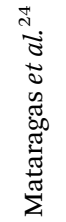
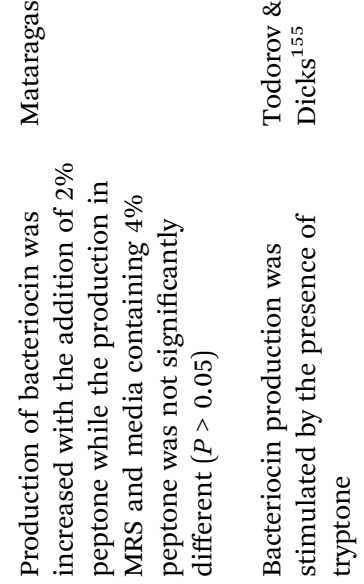

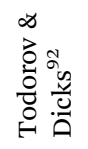

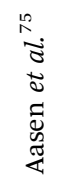

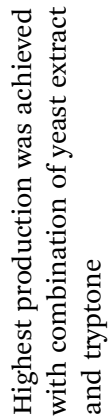

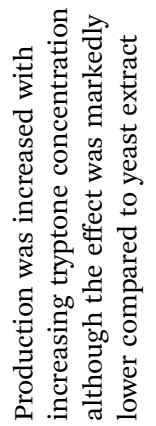

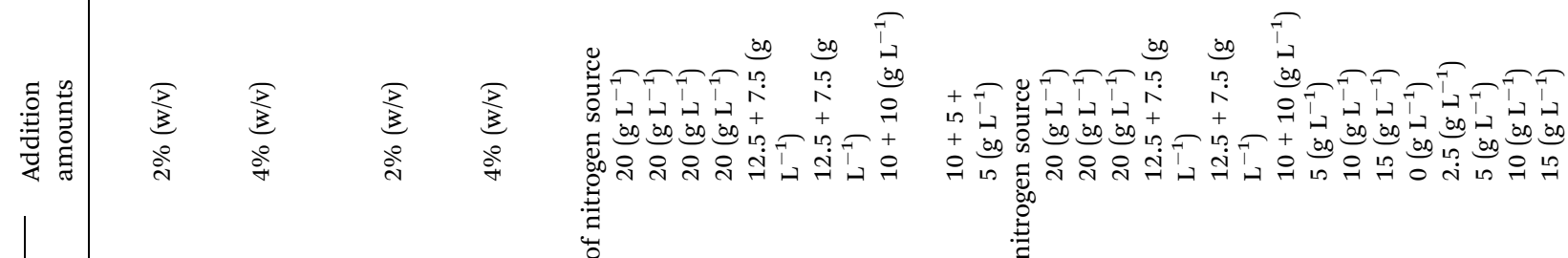
苍

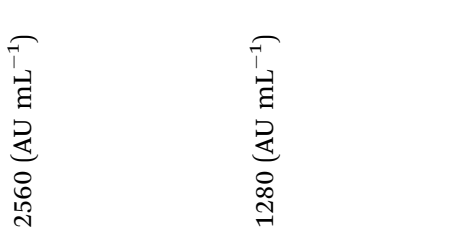

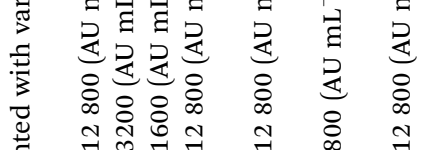

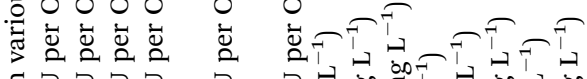

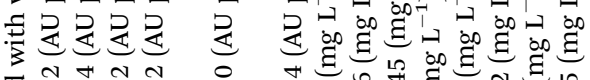

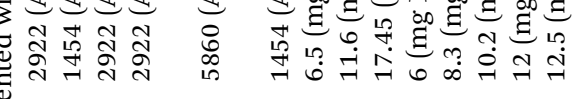

文

$\Sigma$

$\Sigma$

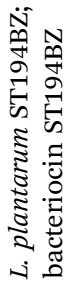

$\sum$

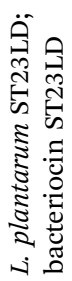

$=$

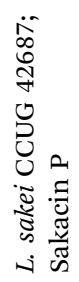




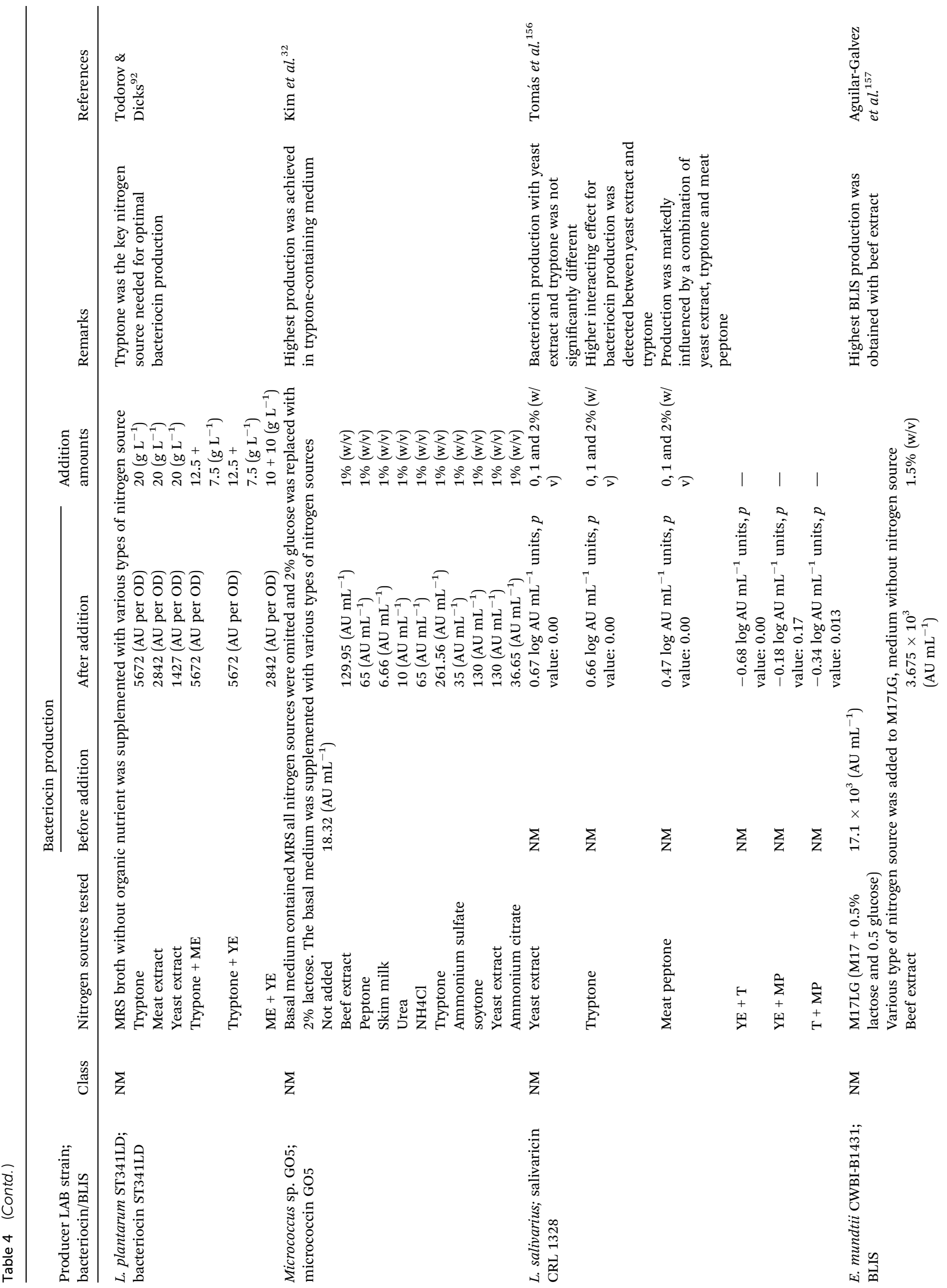




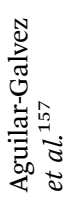

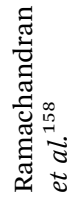

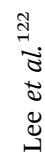

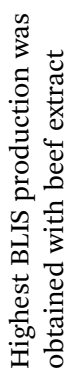
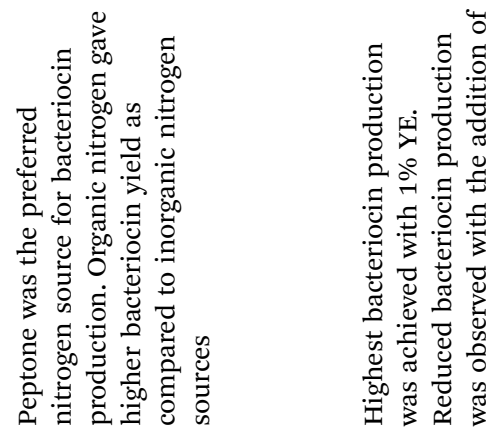

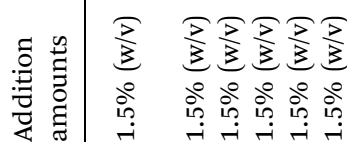

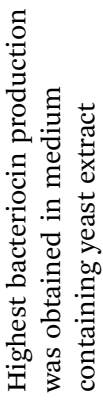

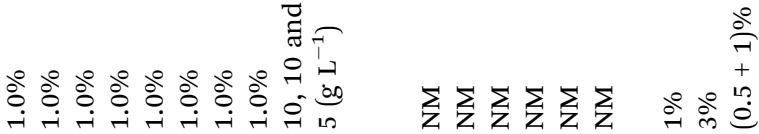

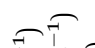

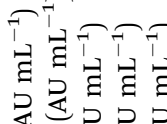

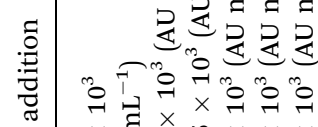

일

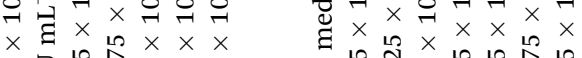

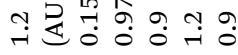

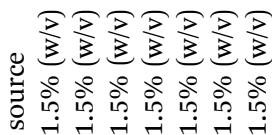

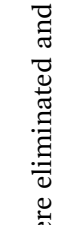

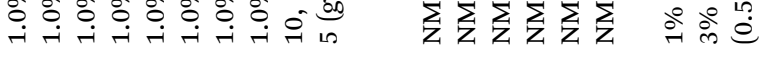
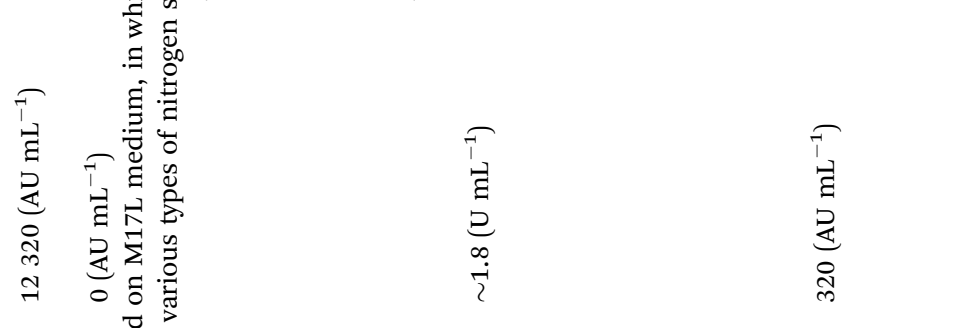

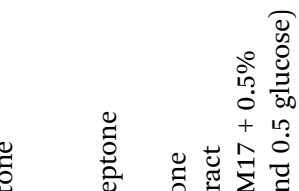

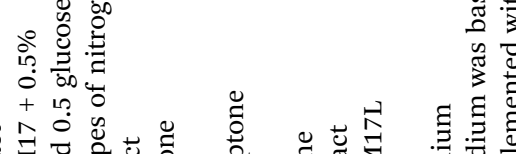

尊彭

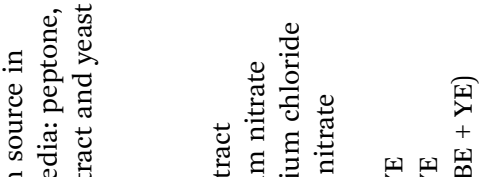

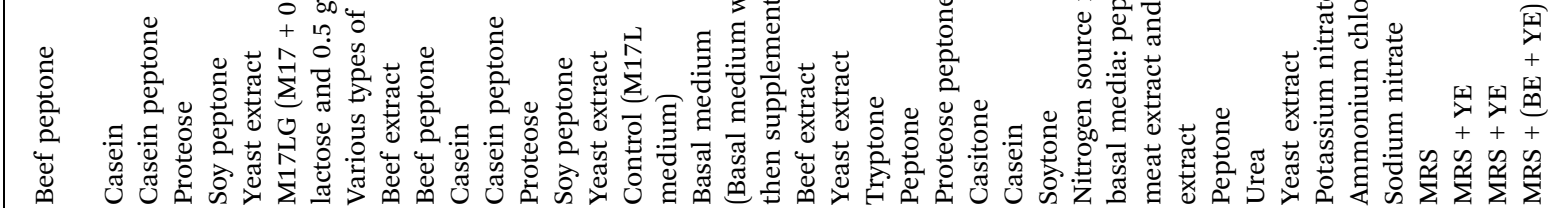

$\sum$

$=$
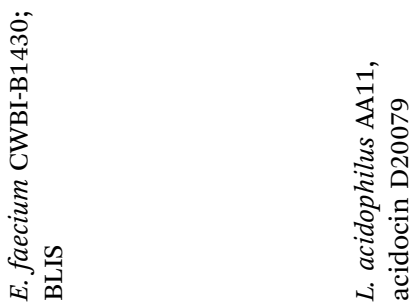

$\sum$

$\sum$ 


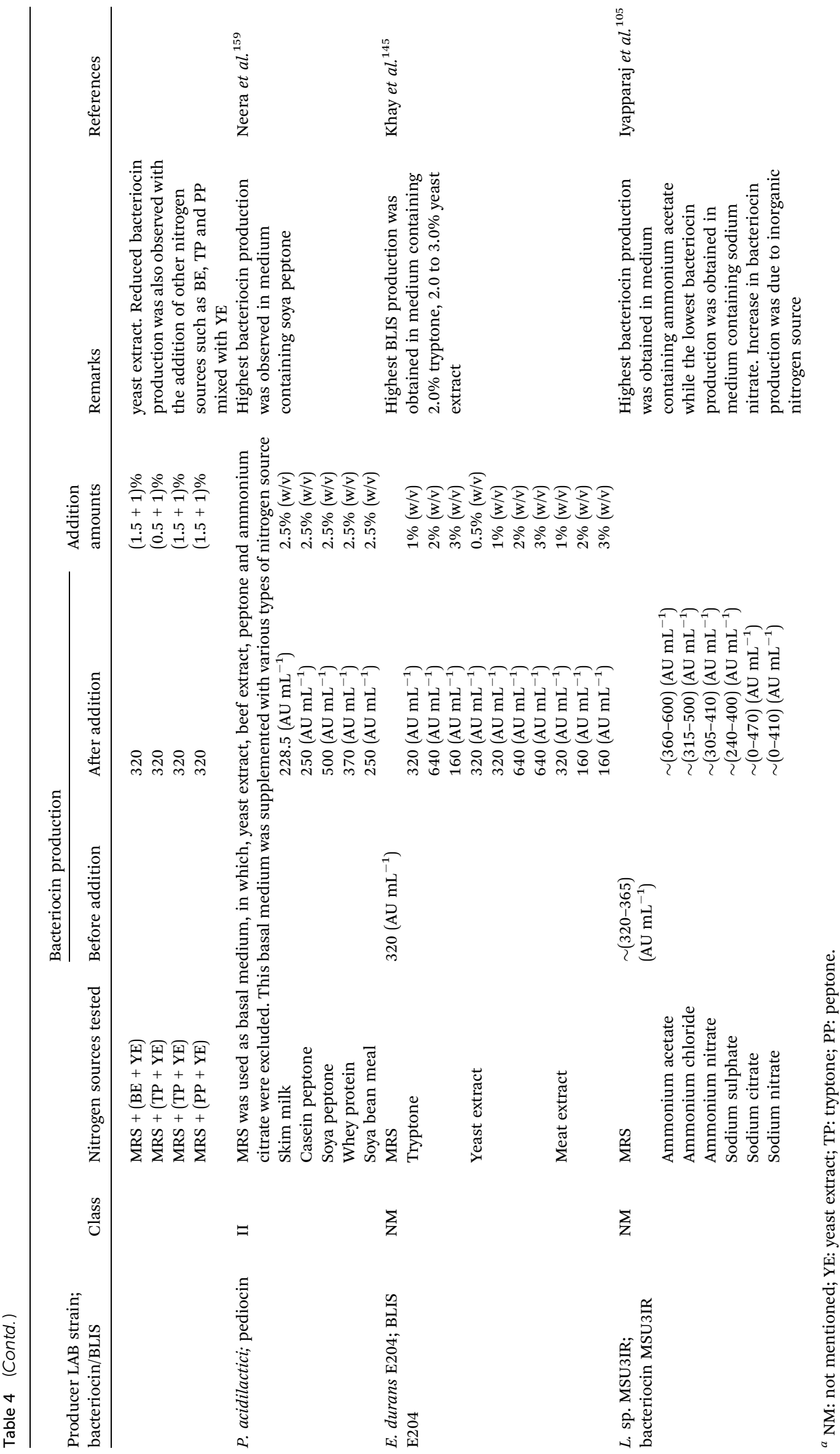


that contain several peptones at high concentration, in which, only a small proportion of peptones supplied are consumed during the fermentation. ${ }^{74}$ Peptones in commercial media are also necessary for bacteriocin production but the efficiencies (substrate consumed/initial substrate) of these media are usually low suggesting the proportions of nutrients in it is unbalanced. $^{70}$

Attempts have been made to balance the medium by the usual procedure of reducing the initial protein level to a slight excess with regard to consumption. However, often the results are marked drops in the production of biomass and typical metabolites, in particular bacteriocins. Furthermore, protein materials which remain after the incubation constitute superfluous expenditure and hinder subsequent purification of the bacteriocins. Replacement of these proteins by inorganic sources of nitrogen does not produce acceptable results and are not suitable for adjusting the initial protein level to the predicted amount for consumption. As peptones do not represent a source of organic nitrogen but rather a source of amino acids or peptides with specific roles, only a fraction added is really important. Therefore, the use of low-cost protein fractions will bring about a reduction in large-scale production costs. ${ }^{74}$

The replacement of half amount of yeast extract with either beef extract or malt extract resulted in the reduction in biomass from L. sakei CCUG 42687 and bacteriocin production. ${ }^{75}$ Moreover, growth and bacteriocin production were markedly improved with the replacement of tryptone with bacteriological peptone or soytone, while the use of a fish hydrolysate reduced growth of L. sakei. ${ }^{76}$ When peptone, beef extract, and yeast extract were replaced in food grade medium by Baker's yeast peptone, L. plantarum was able to grow whereas other lactobacilli strains such as L. acidophilus, L. delbrueckii subsp. bulgaricus, and L. delbrueckii subsp. lactis failed to grow. ${ }^{77}$

LAB are incapable of growing in medium using mineral nitrogen devoid of exogenous amino acids. It is however responsive to changes in the availability of nitrogen in its environment brought about by regulating the proteolytic system to ensure that there is a proper nitrogen balance within the cell. The level of individual nutrients in the extracellular environment has some influence in the synthesis of many exo-proteins. ${ }^{78}$ Nitrogen limitation appears to be attributed to the fastidious nutritional requirement of the LAB which is especially true when there could be a significant level of nitrogen which remained at the end of fermentation. In this respect energy (carbon) metabolism and biosynthesis (nitrogen) metabolism in LAB do not overlap paving the way for metabolic engineering. In this respect it is possible to change either metabolism which do not influence the other provided energy generation or biosynthesis of cell material remain intact. ${ }^{64,75}$ Enhanced bacteriocin production due to increasing nitrogen content could be attributed to the increased in peptide and/or growth factors in the nitrogen sources which is an essential element or an inducer in the synthesis of bacteriocin.

\section{Surfactants}

The effects of surfactant on the production of antimicrobial substances by various LAB strains are summarized in Table 5. In some cases the addition of surfactants increased the concentration of bacteriocins produced as a consequence of cell growth acceleration. Surfactants may enhance the sensitivity of the indicator strain and form micelles with proteinaceous compounds thus stabilizing the bacteriocins. ${ }^{79,80}$

Tween 80 as a surfactant is the most important medium component for the enhancement of bacteriocin production by some LAB strains. ${ }^{27}$ This is brought about by Tween 80 stimulating the secretion of peptides through its influence on membrane fluidity. This product is a non-ionic detergent and a water-soluble ester of oleic acid in which growth of microorganisms is enhanced with their presence. Oleic acid has been known to be an essential growth factor for several microorganisms while non-ionic detergents containing oleic acid, free oleic acid and cis-vaccenic acid can be used to replace the requirement for biotin by lactobacilli. ${ }^{81}$ The presence of Tween 80 in the culture helped to incorporate oleic acid into the cell membrane and oleic acid is then converted into cyclopropane fatty acids. ${ }^{82}$ It is believed that the role of cyclopropane fatty acids is to increase fluidity of LAB membranes as in the case of polyunsaturated fatty acids and to protect LAB from different environmental conditions viz. low $\mathrm{pH}$, deleterious effects of oxygen, and extreme temperatures. ${ }^{83}$ Several reports claimed that Tween 80 improved the production of bacteriocin by preventing the aggregation of their molecules. ${ }^{\mathbf{8 4}}$ Tween 80 could change the surface tension of the producer cell and facilitates the discharge/release of bacteriocin from the cell surface. ${ }^{85}$ This could be brought about by the formation of micelles in the presence of proteins in the medium which stabilized the production of bacteriocin.

Addition of SDS in culture medium resulted in enhanced bioactivity which could be due to the increased permeability of the cell membrane of indicator organism or due to the break up of bacteriocin complex into active subunits with enhanced lethal effect. ${ }^{86}$ Bacteriocin production is enhanced in the presence of a polysorbate non-ionic surfactant Tween 20 by suppressing the adhesion of bacteriocin-producing cells and due to its effect on membrane fluidity and stimulation of the secretion of proteins. ${ }^{87}$ The presence of Tween 20 in the culture enhanced the activity of the bacteriocin produced by L. sakei/curvatus ACU-1. ${ }^{88}$

\section{Effect of cultivation condition}

\section{Temperature}

Temperature play an important role on bacteriocin production. The optimum temperature for growth and bacteriocin production are correlated as observed in lactocin A, ${ }^{89}$ enterocin 1146 and lactocin $\mathrm{S},{ }^{\mathbf{9 0}, 91}$ nisin $\mathrm{Z}^{\mathbf{5 3 , 9 2}}$ plantaricin $^{\mathbf{9 3}}$ and enterocin 1146. ${ }^{94}$ The optimal temperature for bacteriocin production may not be similar to that of optimal temperature for bacterial growth. ${ }^{21,30,95,96}$ There are also reports on maximum bacteriocin production at suboptimal growth temperatures. In the case of amylovorin L471, slow growth at low temperature was suggested 


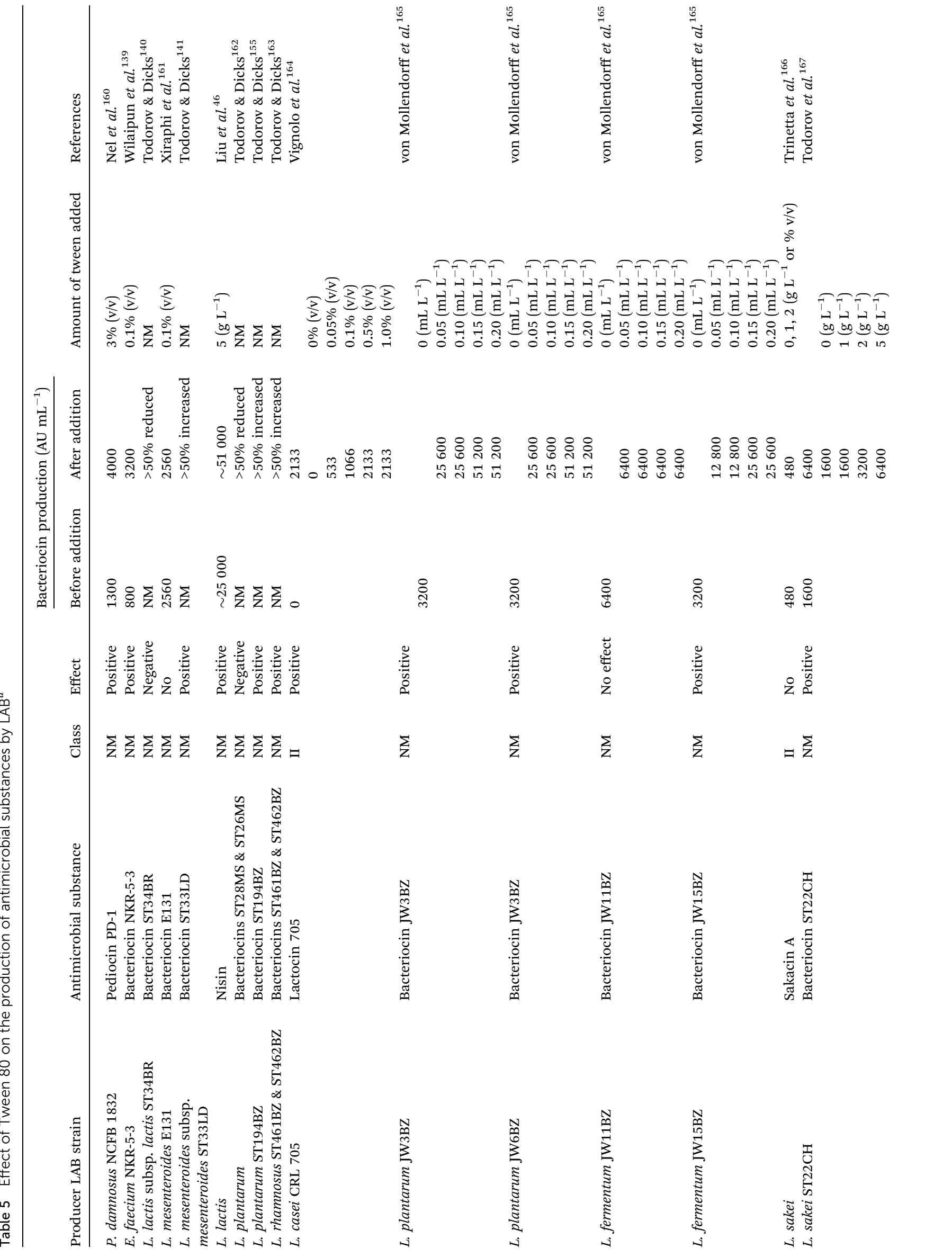




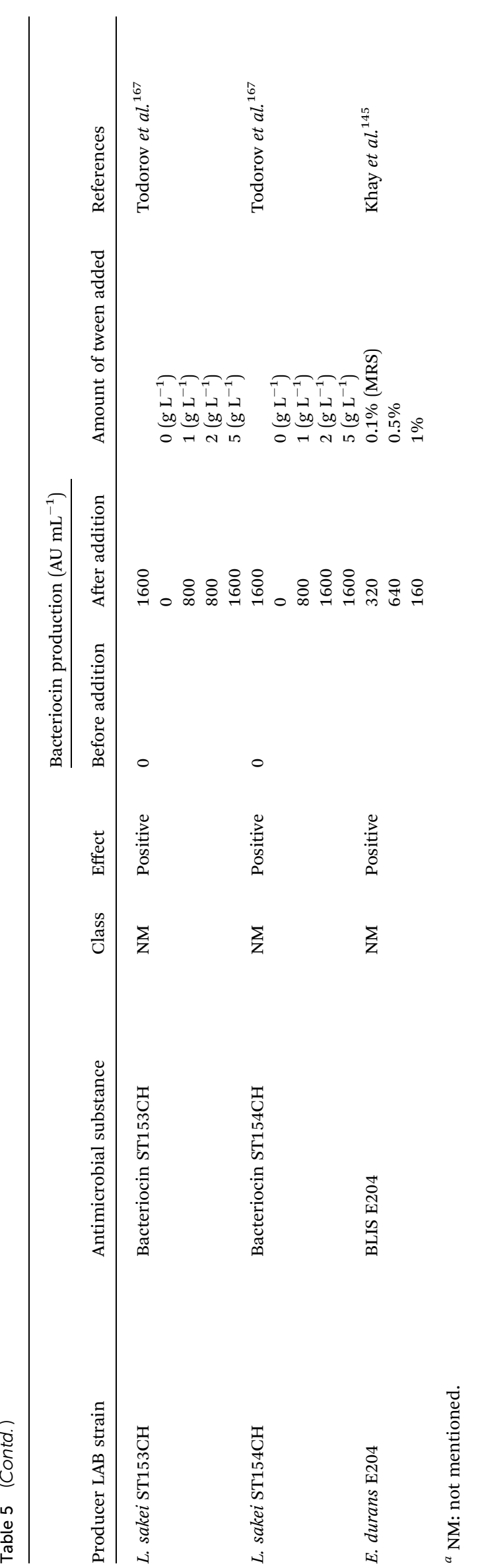

to be attributed to the release of more energy for bacteriocin production by L. amylovorus DCE $471 .{ }^{91}$ As for sakacin P, higher bacteriocin production at low temperatures was reported to be due to different rate-limiting reactions which are temperaturedependent resulting in better utilization of carbon and/or energy. Growth rates was low at low temperature, which in turn increased the availability of essential metabolites (ATP included) for bacteriocin production. Increased in degradation or inactivation of the bacteriocin at high temperatures is another explanation. ${ }^{84}$ An interesting observation is the temperature sensitivity of sakacin A, which is regulated by a three-component regulatory system, ${ }^{97}$ although the optimal temperature was not as low as that required for sakacin P. ${ }^{84}$

Optimum incubation temperature and $\mathrm{pH}$ on growth of various LAB strains and production of bacteriocin is summarized in Table 6 . The optimum incubation temperature for high yield bacteriocin production must be evaluated on individual basis and on the basis of strain-dependence. The optimum temperature for bacteriocin production in most strains isolated to date ranged from $30{ }^{\circ} \mathrm{C}$ to $37{ }^{\circ} \mathrm{C} .{ }^{98}$ However, at high temperature $\left(44^{\circ} \mathrm{C}\right)$ synthesis or production of bacteriocin by microorganism could be curtailed despite possible cell growth under those conditions. ${ }^{14,99}$ Research by Lim $^{100}$ confirmed the work of Messens et al. ${ }^{101}$ who suggested the rate of bacteriocin inactivation increased with high temperature which is probably the result of higher protease activity or a more pronounced cellbacteriocin or bacteriocin-bacteriocin interaction.

\section{pH}

The metabolic activity of LAB is greatly affected by the medium and culture $\mathrm{pH}$. LAB are generally fastidious on artificial media but they grow readily in most food substrates, produce acids and reduce the culture $\mathrm{pH}$ rapidly to a point where other competing microorganisms are no longer able to grow. However the formation of organic acids depended on the type of fermentation, duration, temperature, substrate and LAB strain. ${ }^{48,102}$ LAB is more acid tolerant compared to other types of bacteria and are more tolerant to a lower and wider $\mathrm{pH}$ range (Table 6). It is well known that culture pH greatly influenced the growth of LAB and bacteriocin production apart from influencing cell aggregation, cell absorption of bacteriocin and/or proteolytic degradation. Bacteriocin is produced within a specific $\mathrm{pH}$ range which varies with the producer strains and can be quite different from the $\mathrm{pH}$ range at which the bacteriocin is stable and active. ${ }^{103} \mathrm{pH}$ controls enzymatic reaction hence due to low $\mathrm{pH}$ and accumulation of lactic acid or exhausted energy source, cell growth ceases or stops and so does bacteriocin production. Since immunity of the bacteriocin producer cells is based on the production of immunity peptides whose genes are co-transcribed with the bacteriocin structural genes its level will also decrease when bacteriocin production ceases. ${ }^{104}$

Optimal $\mathrm{pH}$ for the growth or bacteriocin production is markedly dependent on the characteristics of microbial strains used. Optimal $\mathrm{pH}$ for some bacteriocins production ranged from $\mathrm{pH} 5.5$ to 6.0 while for others being less than $\mathrm{pH} 5 .^{105}$ 


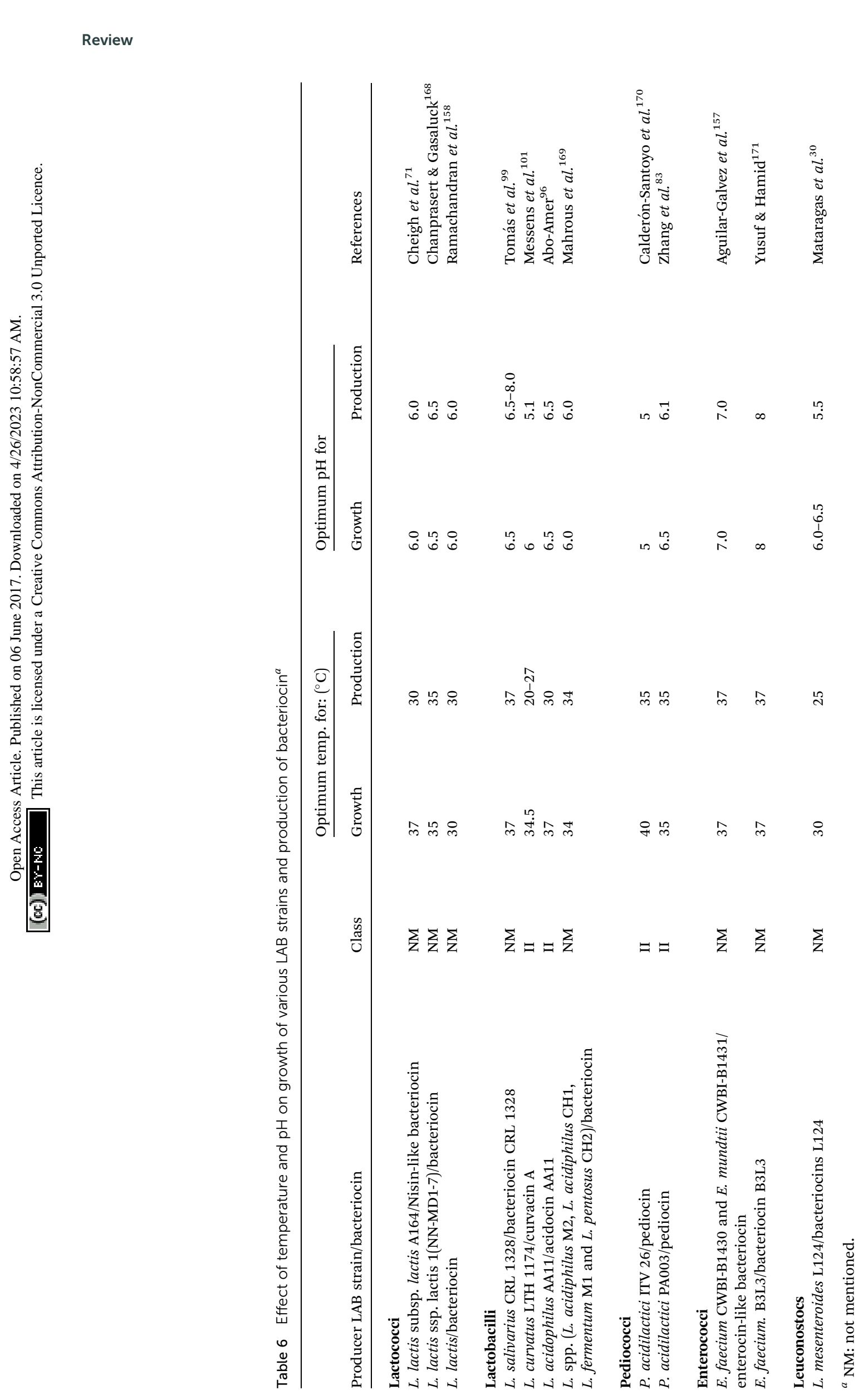

View Article Online
RSC Advances

This journal is (c) The Royal Society of Chemistry 2017

RSC Adv., 2017, 7, 29395-29420 | 29411 
These $\mathrm{pH}$ values are however different from the optimal $\mathrm{pH}$ for bacterial growth. Bacteriocin production being dependent on $\mathrm{pH}$ is an indication that $\mathrm{pH}$ could regulate the expression of biosynthetic gene similarly observed for several classes of genes. ${ }^{33}$ With low growth rate there is better utilization of energy resulting in enhanced bacteriocin production. The enzymatic reactions in the utilization of energy are regulated by $\mathrm{pH}$. Reduction in $\mathrm{pH}$ may decrease the enzymatic reaction, which in turn, reduce the growth rate of the bacterium. The positive effect is therefore on bacteriocin synthesis as a result of net increase of essential metabolites including ATP. ${ }^{84}$ The acidification of medium during fermentation could also affect to protein solubility and hydrolysis of polypepties. ${ }^{\mathbf{1 0 6}}$

It can be deduced from the above reports that the most critical physiochemical factors which play a crucial role and exert a significant effect on bacteriocin production by bacteriocinogenic strains are $\mathrm{pH}$ and temperature. Bacteriocin production was highest at $\mathrm{pH}$ ranging from 5.5 to 6.0 with temperature slightly lower than that for optimal growth..$^{\mathbf{3 0 1 0 7 , 1 0 8}}$ Production of some bacteriocins is enhanced at low pH (5.0). Since the synthesis of bacteriocin is enhanced at a relatively low growth rates, bacteriocin production by some LAB is enhanced at non-optimal growth conditions. Increased in growth rate did not necessarily enhanced bacteriocin production. Lower growth rates at sub-optimal $\mathrm{pH}$ or temperature values indicate potentially better utilization of energy and essential metabolites. ${ }^{75,84}$ At high temperatures or $\mathrm{pH}$, bacteriocin production is lower because energy needs for maintenance purposes are higher when temperature or $\mathrm{pH}$ increases. Maintenance operations such as turnover of macromolecules (DNA, RNA) and maintenance of the potential along the membrane of cells are growth dependent and faster growth rates mean more energy is required for maintenance. However, there are cases of better bacteriocin production at temperatures close to that of optimum for growth. ${ }^{107,108}$ The optimum $\mathrm{pH}$ and temperature for cell growth did not correspond well with those requirements for the enhancement of bacteriocin synthesis. ${ }^{99}$

\section{Aeration and agitation}

The availability of oxygen has a great influence on microbial growth. Microorganisms vary with respect to their requirements and tolerance toward molecular oxygen. $\mathrm{LAB}$ are facultative anaerobic microorganisms where they are capable of modifying a central part of their metabolic pathways according to the availability of oxygen in the medium. This ability allows their classification into homo- and heterolactics. ${ }^{109}$ With no oxygen required for growth this element in fact has a negative effect on the growth of these microbes. Being aerotolerant microorganisms growth of LAB is generally slightly affected by oxidative stress. ${ }^{20}$

Some bacteria especially those that are anaerobic are not capable of synthesizing cytochromes and other heme containing enzymes. L. acidophilus and bifidobacterium spp. lack this capability which is crucial to the electron transportation chain. They are thus unable to synthesize ATP by respiratory means and have to depend strictly on a fermentative mode of metabolism. Due to lack of participation of an external electron acceptor (oxygen in aerobic bacteria) in anaerobes, the organic substrate undergoes a balanced series of oxidative and reductive reactions mediated by pyridine nucleotides such as NADH.

Substrate level phosphorylation is the main source from which anaerobes derived its energy and in this sense regeneration of NAD+ from NAD is of critical importance. Growth rate of $\mathrm{LAB}$ on glucose is enhanced in the presence of $\mathrm{O}_{2}$ more so when catalase is present to eliminate the $\mathrm{H}_{2} \mathrm{O}_{2}$ formed. This observation indicates the rate at of ATP production from sugars is a growth-rate limiting factor in LAB cultures. ${ }^{\mathbf{1 1 0}}$

Generally, production of bacteriocins in LAB cultures is a reflection of either a moderately or highly restrictive condition with regards to the availability of oxygen in the medium. ${ }^{109}$ The situation could be more complex if the facultative anaerobic nature of the LAB is taken into consideration. Effects of aeration and agitation on bacteriocin production are strain dependent (Table 7). Amiali et al., ${ }^{111}$ claimed that nisin A production by $L$. lactis UL719 in fed batch fermentation was enhanced with aeration largely due to increase in cell-bound activity. On the other hand, aeration has been reported to be antagonistic to the production of nisin A, ${ }^{\mathbf{1 1 2}}$ lactosin $\mathrm{S},{ }^{\mathbf{8 9}}$ and LIQ-4 bacteriocin. ${ }^{\mathbf{1 1 3}}$ Furthermore, the production of nisin by L. lactis requires anaerobiosis, or that "typical conditions" imply moderate agitation or absence of agitation. ${ }^{\mathbf{1 1 4 - 1 1 6}}$ Cabo et al.,${ }^{117}$ found, with the same strain, maximum production under clearly aerobic conditions. Production at the maximum biomass point quadrupled when the oxygen saturation percentage was increased from 50 to $100 \%$ saturation. Vázquez et al., ${ }^{109}$ reported that under the extreme conditions the production of bacteriocin continued after the biomass reached the asymptotic value; this did not occur under intermediate conditions. The observation suggests that bacteriocin can change its metabolic character (primary or secondary) in response to the conditions of aeration. Reduced bacteriocin activity with increasing degree of agitation has been reported which could be due to chemical degradation and effects on gene expression. ${ }^{118}$ The growth of $P$. acidilactici Kp10 increased with increasing agitation speed from 100 to $800 \mathrm{rpm}$ but production of bacteriocin was only increased up to $400 \mathrm{rpm}$ and significantly reduced at agitation of above $500 \mathrm{rpm} .{ }^{103}$ It was also reported that a culture without agitation was preferred for Pediocin Iz3.13 production by $P$. pentosaceus Iz.3.13. ${ }^{119}$ Several pediocin-like bacteriocins contain methionine residues whose sulfur atom could be oxidized resulting in bacteriocin destabilisation in solution with the presence of oxygen. ${ }^{\mathbf{1 2 0}}$

Agitation is required to improve oxygen supply to the culture during the cultivation in stirred tank bioreactor. However, agitation is also related to shear rate effect. The degree of agitation has several effects on microbial growth which include cell wall disruption, changes in growth morphology, variations in the rates of growth and rates of formation of the desired product. ${ }^{121}$

\section{Optimization process for improvement of bacteriocin production}

Optimization of the fermentation process parameters is possible for the improvement of the production of bioactive 

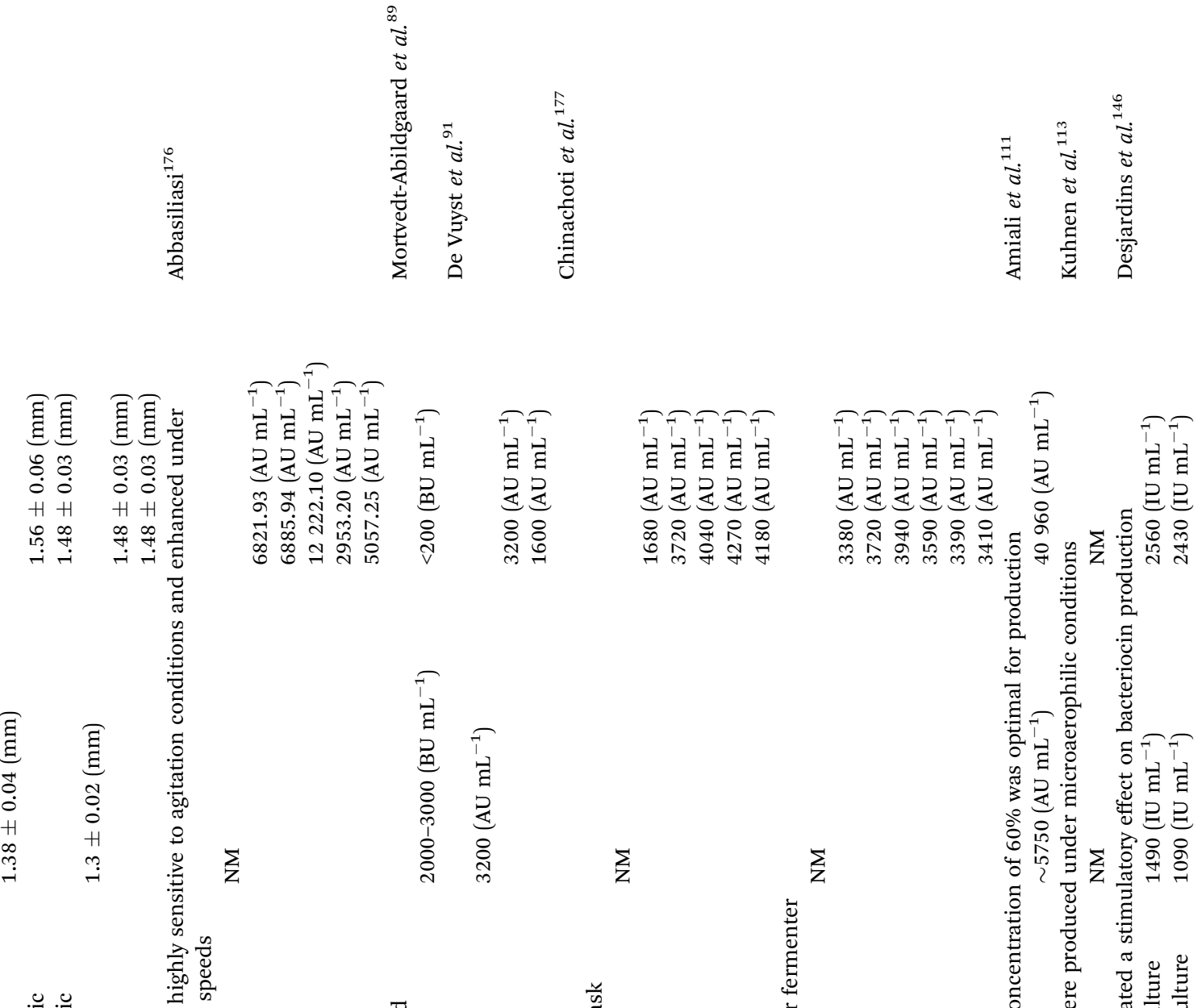

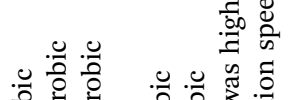

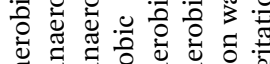

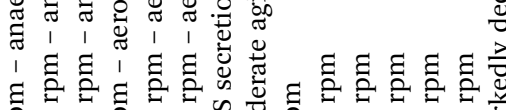

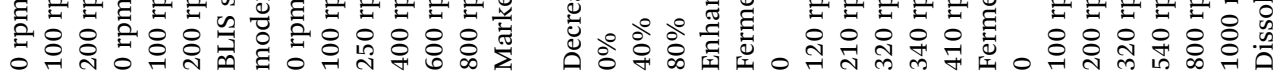

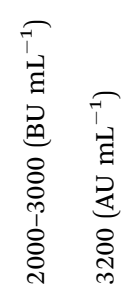

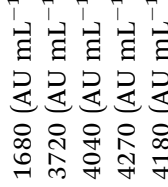

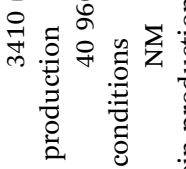

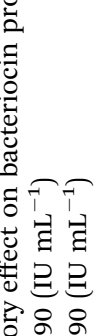
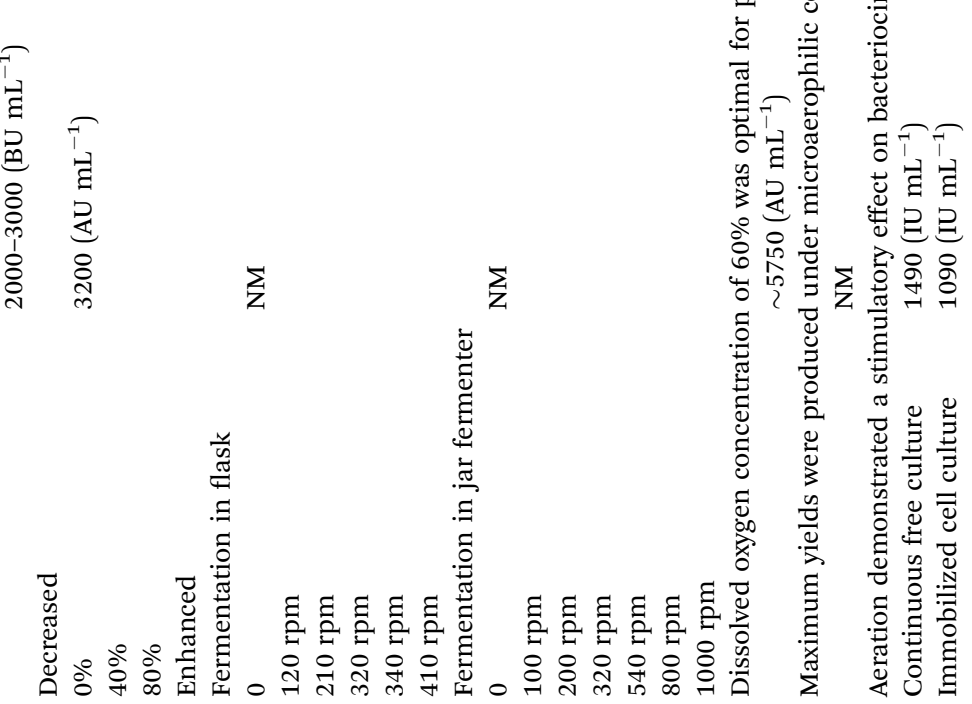

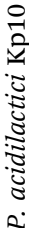
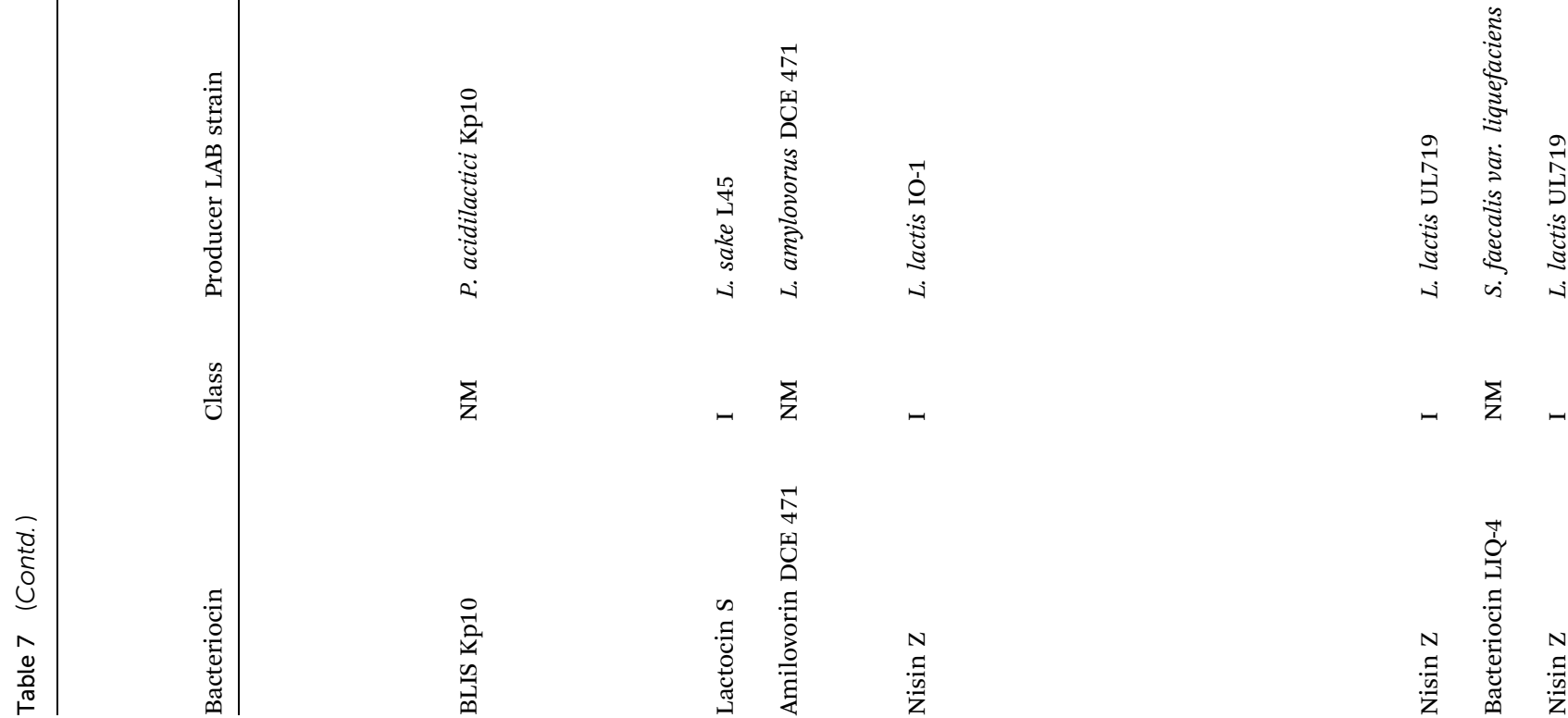

$\bar{\Sigma}$

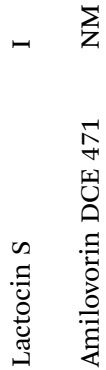

$\stackrel{N}{: 0}$

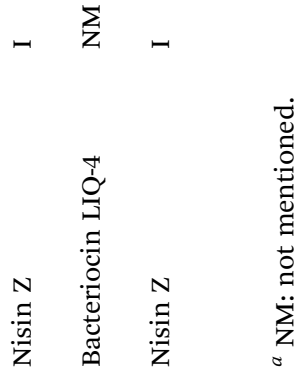


peptides, which are of great interest for the design of functional foods and nutraceuticals. Although finding an optimal production process is a complex problem, but it is essential for the development of economically viable commercial bacteriocin production which leads to high yields and cost-effective process. High production yields are achieved by optimization of culture conditions or medium composition. The growth of bacteria and the accumulation of their metabolites are strongly influenced by the environment and medium compositions such as culture $\mathrm{pH}$, carbon and nitrogen sources, growth factors, and minerals. Detection of these major factors and their optimization for biotechnological processes including multivariables are difficult. ${ }^{122}$ Optimization of fermentation process is time consuming, labor intensive, involves high cost and requires many experimental trials. With the introduction of new mutants and strains, these trials are necessity for industrial applications. The trials entail combinations of different factors and sequence of processes. The influence of medium components also need to be investigated to ensure that the growth conditions which produce the biomass and the physical state are best suited for product formation.

Two different systems, close-end and open-ended, are normally use in the optimization process. In the closed-end system optimization analysis is directed towards a fixed number and types of component parameters. Being a simple strategy many different possible components and/or parameters not given due consideration could be beneficial to the process. In the openended system analysis is on any number and types of components and/or parameters. This system makes no assumption which components/parameters are best suited for the process. The common practice adopted has always been to start off with the open-ended system; the best components/parameters are selected and subsequently followed by the close-ended system.

Specific requirements with reference to the production of bacteriocins have been reported. ${ }^{\mathbf{1 2 3 - 1 2 5}}$ Bacteriocin titers can be modified by altering the cultivation conditions of the producing bacterium and certain combinations of influencing factors could be optimized to enhance bacteriocin production. ${ }^{126}$ With regards to the complexity of the factors within the food environments itself an in-depth knowledge of the interacting factors influencing the production of bacteriocin need to be understood for subsequent application in the optimization process. Most studies carried out to date claimed validation by statistical analysis and a combination of variables. However their values and limits were arbitrarily chosen based primarily on personal experience. ${ }^{103}$

Conventional methods in fermentation optimization require treating each factor separately which is laborious, incomplete and time consuming. If several factors are to be considered simultaneously their interactions are not discernible even for the dominant ones. These conventional approaches did not yield reliable results either. In this respect, experimental factorial design has been successfully applied for the optimization of various biomanufacturing processes which could also be used to investigate the interacting factors. ${ }^{103,127,128}$

Response surface methodology (RSM), a non-conventional approach is a collection of statistical and mathematical methods that could be used to quantify the interaction between different factors. This approach provides statistically reliable results with fewer number of experiments and are very useful for the development, improvement and optimization of the biomanufacturing processes. ${ }^{\mathbf{1 2 9 - 1 3 1}}$ RSM is based on analysis of responses induced by specific factors. This methodology is also useful in determining the direction of subsequent experiment towards an optimum point where the equation can be determined from the optimization point of the response surface. ${ }^{\mathbf{1 0 3 , 1 3 2}}$ This method was successfully applied in many areas of biotechnology, including some studies on bacteriocin production (Table 8 ).

Artificial neural network (ANN) on the other hand has recently emerged as one of the most efficient methods for empirical modeling and prediction in solving complex systems such as bacteriocin production. Several studies have demonstrated that the accuracy for the prediction of ANN models was far more superior compared to RSM using the same experimental design. ANN does not require prior specification of a suitable fitting function. ANN has the universal approximation capability which means that it can approximate almost all types of non-linear functions including quadratic functions. The ability of ANN to predict process characteristics with little prior knowledge is desirable which simplifies their implementation and increases their modeling potential. This property makes ANN a powerful and flexible tool that is well-suited for modeling biochemical processes. ${ }^{\mathbf{1 0 3 , 1 3 3 - 1 3 5}}$ Several reports have demonstrated that the predictive accuracy of ANN model was superior to RSM model using the same experimental design. ${ }^{\mathbf{1 3 4}, \mathbf{1 3 6}-\mathbf{1 3 8}}$ However, ANN is known as a black box modeling approach. The effect of factors on response values and the interaction effect among the factors cannot be studied by ANN model.

Several statistical methods such as response surface methodology (RSM) and artificial neural network (ANN) have been applied in the optimization of LAB fermentation for improvement of bacteriocin production (Table 8). Substantial improvement in bacteriocin production was achieved with optimal medium compositions and/or culture conditions as optimized using RSM and ANN.

\section{Conclusions}

Production of bacteriocin by LAB is greatly influenced by medium formulation and culture conditions. Growth of LAB and bacteriocins production is not only affected by the type of carbon (C) and nitrogen (N) sources but also by their concentrations and ratios. The presence of surfactant in the culture medium also improved the production of bacteriocins by some LAB strains. Besides the culture $\mathrm{pH}$, aeration and oxygen supply also exert significant effect on growth of some LAB strains and bacteriocin production. Statistical methods such as RSM and ANN have been used successfully to optimize the culture condition and medium formulations for improvement of growth of LAB and bacteriocin production. 


\section{References}

1 D. Cizeikiene, G. Juodeikiene, A. Paskevicius and E. Bartkiene, Food Control, 2013, 31, 539-545.

2 A. Digaitiene, A. S. Hansen, G. Juodeikiene, D. Eidukonyte and J. Josephsen, Eur. J. Appl. Microbiol., 2012, 112, 732-742.

3 E. Bartkiene, V. Bartkevics, E. Mozuriene, V. Krungleviciute, A. Novoslavskij, A. Santini, I. Rozentale, G. Juodeikiene and D. Cizeikiene, Food Control, 2017, 71, 285-292.

4 E. Kuley, F. Ozogul, Y. Ozogul and I. Akyol, Food Chem., 2011, 129, 1211-1216.

5 E. Bartkiene, V. Bartkevics, V. Starkute, D. Zadeike and G. Juodeikiene, Front. Plant Sci., 2016, 7, 951-954.

6 S. Abbasiliasi, J. S. Tan, T. A. T. Ibrahim, R. N. Ramanan, F. Vakhshiteh, S. Mustafa, T. C. Ling, R. A. Rahim and A. B. Ariff, BMC Microbiol., 2012, 1, 260.

7 J. Slapkauskaite, D. Sekmokiene, A. Kabasinskiene, E. Bartkiene, G. Juodeikiene and A. Sarkinas, CyTA-J. Food, 2016, 14, 482-488.

8 S. Elayaraja, N. Annamalai, P. Mayavu and T. Balasubramanian, Asian Pac. J. Trop. Biomed., 2014, 4, 305-311.

9 S.-C. Yang, C.-H. Lin, C. T. Sung and J.-Y. Fang, Front. Aquat. Microbiol., 2014, 5, 1-10.

10 C. Bramsiepe, S. Sieversa, T. Seiferta, G. D. Stefanidisb, D. G. Vlachosc, H. Schnitzerd, B. Mustere, C. Brunnere, J. P. M. Sandersf, M. E. Bruinsf and G. Schembeckera, Chem. Eng. Process., 2012, 51, 32-52.

11 G. Kaur and I. Roy, Chem. Biochem. Eng. Q., 2015, 29, 157172.

12 M. V. Leal-Sánchez, R. Jiménez-Díaz, A. MaldonadoBarragán, A. Garrido-Fernández and J. L. Ruiz-Barba, Appl. Environ. Microbiol., 2002, 68, 4465-4471.

13 W. Lv, X. Zhang and W. Cong, Appl. Microbiol. Biotechnol., 2005, 68, 322-326.

14 F. Leroy and L. De Vuyst, Appl. Environ. Microbiol., 1999, 3, 974-981.

15 S. H. Al-Zahrani and F. S. Al-Zahrani, World Appl. Sci. J., 2006, 1, 135-143.

16 H. Abriouel, E. Valdivia, M. Mart nez-Bueno, M. Maqueda and A. Gallvez, J. Microbiol. Methods, 2003, 55, 599-605.

17 J. C. J. Coetzee, Master of Science in Engineering, University of Stellenbosch, 2007.

18 E. Parente and A. Ricciardi, Appl. Microbiol. Biotechnol., 1999, 52, 628-638.

19 A. Aktypis, M. Tychowski, G. Kalantzopoulos and G. Aggelis, Antonie van Leeuwenhoek, 2007, 92, 207-220.

20 F. Leroy, S. Vankrunkelsven, J. De Greef and L. De Vuyst, Int. J. Food Microbiol., 2003, 83, 27-38.

21 C. Li, J. Bai, Z. Cai and F. Ouyang, J. Biotechnol., 2002, 1, 27-34.

22 M. D. Altaf, B. J. Naveena and G. Reddy, Bioresour. Technol., 2007, 98, 498-503.

23 S. A. Hayek and S. A. Ibrahim, Food Nutr. Sci., 2013, 4, 73-87.

24 M. Mataragas, E. H. Drosinos, E. Tsakalidou and J. Metaxopoulos, Antonie van Leeuwenhoek, 2004, 85, 191-198.
25 B. Rivas, A. B. Moldes, J. M. Dominguez and J. C. Parajó, Int. J. Food Microbiol., 2004, 97, 93-98.

26 N. P. Guerra, A. T. Agrasar, C. L. Macias and L. Pastrana, Process Biochem., 2005, 40, 1071-1083.

27 T. Zendo, N. Eungruttanagorn, S. Fujioka, Y. Tashiro, K. Nomura, Y. Sera, G. Kobayashi, J. Nakayama, A. Ishizaki and K. Sonomoto, J. Appl. Microbiol., 2005, 99, 1181-1190.

28 C. Herranz, J. Martinez, J. Rodriguez, P. Hernandez and L. M. Cintas, Appl. Microbiol. Biotechnol., 2001, 56, 378-383.

29 J. Verluyten, F. Leroy and L. De Vuyst, Appl. Environ. Microbiol., 2004a, 70, 5081-5088.

30 M. Mataragas, J. Metaxopoulos, M. Galiotou and E. H. Drosinos, Meat Sci., 2003, 64, 265-271.

31 F. Cladera-Olivera, G. R. Caron and A. Brandelli, Biochem. Eng. J., 2004, 21, 53-58.

32 M.-H. Kim, Y.-J. Kong, H. Baek and H.-H. Hyun, J. Biotechnol., 2006, 121, 54-61.

33 A. S. Motta and A. Brandelli, World J. Microbiol. Biotechnol., 2008, 24, 641-646.

34 G. Medaglia and S. Panke, Appl. Microbiol. Biotechnol., 2010, 87, 145-157.

35 E. V. Pingitore, E. M. Hebert, F. Sesma and M. E. NaderMacias, Can. J. Microbiol., 2009, 55, 304-310.

36 F. M. Saguir and M. C. M. de Nadra, Curr. Microbiol., 2007, 54, 414-418.

37 N. Terrade, R. Noel, R. Couillaud and R. M. de Orduna, Food Res. Int., 2009, 42, 363-367.

38 H. Khan, S. H. Flint and P.-L. Yu, JAM, 2012, 114, 10921102.

39 B. Mandal, R. Chowdhury, C. Bhattacharjee and R. Haque, Int. J. Biomed. Res., 2013, 6, 39-51.

40 J. A. Vazquez, M. P. Gonzalez and M. A. Murano, J. Biotechnol., 2004, 112, 299-311.

41 S. F. Deraz, G. F. El-Fawal, S. A. Abd-Ellatif and A. A. Khalil, Indian J. Microbiol., 2011, 51, 171-175.

42 H. Oh, Y.-J. Wee, J.-S. Yun, H. S. Ho, S. Jung and H.-W. Ryu, Bioresour. Technol., 2005, 96, 1492-1498.

43 Y. Wee, J. Kim and H. Ryu, Food Technol. Biotechnol., 2006, 44, 163.

44 A. F. Jozala, D. P. Silva, A. A. Vicente, J. A. Teixeira, A. Pessoa Junior and T. C. V. Penna, Afr. J. Biotechnol., 2011, 10, 14920-14925.

45 S. H. Flôres and R. M. Alegre, Biotechnol. Appl. Biochem., 2001, 34, 103-107.

46 X. Liu, Y.-K. Chung, S.-T. Yang and A. E. Yousef, Process Biochem., 2005, 40, 13-24.

47 M. Mirhosseini and G. Emtiazi, World Appl. Sci. J., 2011, 14, 1493-1499.

48 E. Bartkiene, I. IJakobsone, G. Juodeikiene, D. Vidmantiene, I. Pugajeva and V. Bartkevics, Food Control, 2013, 30, 35-40.

49 J. A. Vazquez, M. P. Gonzalez and M. A. Murado, Bioresour. Technol., 2006, 97, 605-613.

50 R. K. I. Anderson and K. Jayaraman, Chem. Biochem. Eng. Q., 2003, 17, 225-232. 
51 A. Delgado, N. A. Lopez, D. Brito, C. Peres, P. Fevereiro and F. A. Garrido, J. Biotechnol., 2007, 130, 193-201.

52 S. A. Al-Wendawi and A. A. Al-Saady, Medical journal of Babylon, 2012, 9, 386-396.

53 H. Matsusaki, N. Endo, K. Sonomoto and A. Ishizaki, Appl. Microbiol. Biotechnol., 1996, 45, 36-40.

54 R. W. Jack and J. R. Tagg, J. Med. Microbiol., 1992, 36, 132138.

55 S. Even, N. D. Lindley and M. Cocaign-Bousquet, J. Bacteriol., 2001, 183, 3817-3824.

56 M. Papagianni, N. Avramidis and G. Filiousis, Enzyme Microb. Technol., 2007, 40, 1557-1563.

57 J. B. Russell and R. L. Baldwin, Appl. Environ. Microbiol., 1978, 37, 531-536.

58 S. A. Martin and J. B. Russell, Appl. Environ. Microbiol., 1987, 53, 2388-2393.

59 J. B. Russell, Appl. Environ. Microbiol., 1990, 56, 3304-3307.

60 A. P. Dominguez, D. Bizani, F. Cladera-olivera and A. Brandilli, Biochem. Eng. J., 2007, 35, 238-243.

61 Y. Ohkouchi and Y. Inoue, Bioresour. Technol., 2006, 97, 1554-1562.

62 S. Sanchez and A. L. Demain, Enzyme Microb. Technol., 2002, 31, 895-906.

63 S. Dimov, S. Peykov, D. Raykova and P. Ivanova, Trakia Journal of Sciences, 2008, 6, 54-59.

64 N. P. Guerra, M. L. Rua and L. Pastrana, Int. J. Food Microbiol., 2001, 70, 267-281.

65 A. H. de Rojas, B. Martinez, J. E. Suárez and A. Rodríguez, Appl. Microbiol. Biotechnol., 2004, 66, 48-52.

66 P. Pattnaik, S. Grover and V. K. Batish, Microbiol. Res., 2005, 160, 213-218.

67 M. Ferchichi, E. Crabbe, W. Hintz, G.-H. Gil and A. Almadidy, World J. Microbiol. Biotechnol., 2005, 21, 855862.

68 M. S. Kalil, H. S. Alshiyab and W. M. Wan Yusoff, Am. J. Biochem. Biotechnol., 2008, 4, 393-401.

69 M. K. Somda, A. Savadogo, N. Barro, P. Thonart and A. S. Traore, Asian J. Ind. Eng., 2011, 3, 29-33.

70 J. A. Vázquez, M. L. Cabo, M. P. Gonzalez and M. A. Murado, Enzyme Microb. Technol., 2004, 34, 319-325.

71 C.-I. Cheigh, H.-J. Choi, H. Park, S.-B. Kim, M.-C. Kook, T.-S. Kim, J. Kwan Hwang and Y.-R. Pyun, J. Biotechnol., 2002, 95, 225-235.

72 A. Pandey, S. Negi and C. R. Soccol, Current developments in biotechnology and bioengineering: Production, isolation and purification of industrial products, Elsevier, Netherlands, 2016.

73 F. Davami, L. Baldi, Y. Rajendra and F. M. Wurm, International Journal of Mol Cell Med Summer, 2014, 3, 146-156.

$74 \mathrm{~J}$. A. Vázquez and M. A. Murado, J. Chem. Technol. Biotechnol., 2008, 1, 91-96.

75 I. M. Aasen, T. Møretrø, T. Katla, L. Axelsson and I. Storrø, Appl. Microbiol. Biotechnol., 2000, 53, 159-166.

76 T. Lechiancole, A. Ricciardi and E. Parente, Ann. Microbiol., 2002, 52, 257-274.
77 Y. Sawatari, T. Hirano and A. Yokota, J. Gen. Appl. Microbiol., 2006, 52, 349-356.

78 M. C. M. de Nadra, Communicating current research and educational topics and trends in applied microbiology, 2007, pp. 500-510.

79 A. Cheikhyoussef, N. Pogori, W. Chen and H. Zhang, Int. J. Food Microbiol., 2008, 125, 215-222.

80 F. A. C. Martinez, E. M. Balciunas, A. Converti, P. D. Cotter and R. P. de Souza Oliveira, Biotechnol. Adv., 2013, 31, 482488.

81 M. I. Tudor, Master of science, University of the Philippines, 2010.

82 J. K. Jenkins and P. D. Courtney, Can. J. Microbiol., 2003, 49, 51-57.

83 J. Zhang, Y. Zhang, S.-N. Liu, Y. Han and Z.-J. Zhou, Appl. Biochem. Biotechnol., 2012, 166, 1388-1400.

84 T. Møretrø, I. M. Aasen, I. Storrø and L. Axelsson, J. Appl. Microbiol., 2000, 88, 536-545.

85 A. R. Sarika, A. P. Lipton and M. S. Aishwarya, Adv. J. Food Sci. Technol., 2010, 2, 291-297.

86 S. A. Naz and S. A. Rasool, Pak. J. Bot., 2013, 45, 261-267.

87 P. S. Malheiros, V. Sant'Anna, S. D. Todorov and B. D. G. M. Franco, Braz. J. Microbiol., 2015, 46, 825-834.

88 M. P. Castro, N. Z. Palavecino, C. O. Herman, O. A. Garro and C. A. Campo, Meat Sci., 2011, 87, 321-329.

89 C. I. Mortvedt-Abildgaard, J. Nissen-Meyer, B. Jelle, B. Grenov, M. Skaugen and I. F. Nes, Appl. Environ. Microbiol., 1995, 61, 175-179.

90 E. Q. Khay, M. Idaomar, L. M. P. Castro, P. F. Bernanrdez, N. SkaliSenhaji and J. Abrini, Afr. J. Biotechnol., 2011, 10, 10447-11045.

91 L. De Vuyst, R. Callewaert and K. Crabbe, Microbiol, 1996, 4, 817-827.

92 S. D. Todorov and L. M. T. Dicks, Microbiol. Res., 2006, 2, 102-108.

93 J. Li, D. Song and Q. Gu, Weishengwu Xuebao, 2008, 48, 818823.

94 E. Parente and A. Ricciardi, Lett. Appl. Microbiol., 1994, 19, 12-15.

95 G. Rajaram, P. Manivasagan, B. Thilagavathi and A. Saravanakumar, Adv. J. Food Sci. Technol., 2010, 2, 138144.

96 A. E. Abo-Amer, Ann. Microbiol., 2011, 445-452.

97 D. B. Diep and I. F. Nes, Curr. Drug Targets, 2002, 3, 107122.

98 N. Gautam and N. Sharma, Indian J. Microbiol., 2009, 49, 204-211.

99 J. Tomás, E. Bru, B. Wiese, A. A. P. de Ruiz Holgado and M. E. Nader-Macías, J. Appl. Microbiol., 2002, 93, 714-724.

100 S.-M. Lim, Food Sci. Biotechnol., 2010, 19, 793-802.

101 W. Messens, J. Verluyten, F. Leroy and L. De Vuyst, Int. J. Food Microbiol., 2003, 81, 41-52.

102 E. Bartkiene, V. Krungleviciute, G. Juodeikiene, D. Vidmantiene and Z. Maknickiene, J. Sci. Food Agric., 2015, 95, 1336-1342. 
103 S. Abbasiliasi, J. S. Tan, S. Kadkhodaei, R. Nelofer, T. A. Tengku Ibrahim, S. Mustafaa and A. B. Ariff, $R S C$ Adv., 2016, 6, 6342-6349.

104 M. Zamfir, R. Callewaert, P. C. Cornea and L. Vuyst, FEMS Microbiol. Lett., 2000, 190, 305-308.

105 P. Iyapparaj, T. Maruthiah, R. Ramasubburayan, S. Prakash, C. Kumar, G. Immanuel and P. Arunachalam, Aquat. Biosyst., 2013, 9, 1-10.

106 D. Klupsaite, G. Juodeikiene, D. Zadeike, E. Bartkiene, Z. Maknickiene and G. Liutkute, LWT-Food Sci. Technol., 2017, 75, 180-186.

107 E. H. Drosinos, M. Mataragas and J. Metaxopoulos, Meat Sci, 2006, 74, 690-696.

108 E. H. Drosinos, M. Mataragas, P. Nasis, M. Galiotou and J. Metaxopoulos, J. Appl. Microbiol., 2005, 99, 1314-1323.

109 J. A. Vázquez, J. Mirón, M. P. González and M. A. Murado, Appl. Biochem. Biotechnol., 2005, 127, 111-124.

110 M. Higuchi, Y. Yamamoto and Y. Kamio, J. Biosci. Bioeng., 2000, 90, 484-493.

111 M. N. Amiali, C. Lacroix and R. E. Simard, World J. Microbiol. Biotechnol., 1998, 14, 887-894.

112 A. Hurst, Adv. Appl. Microbiol., 1981, 27, 85-123.

113 E. Kuhnen, H.-G. Sahl and H. Brandis, J. Gen. Microbiol., 1985, 131, 1925-1932.

114 A. Hirsch, J. Gen. Microbiol., 1951, 5, 208-221.

115 L. De Vuyst, Bacteriocins of Lactic Acid Bacteria: Microbiology, Genetics and Applications, Blackie Academic and Professional, London, UK, 1994.

116 W. S. Kim, R. J. Hall and N. W. Dunn, Appl. Microbiol. Biotechnol., 1998, 50, 429-433.

117 M. L. Cabo, M. A. Murado, M. González and L. Pastoriza, Enzyme Microb. Technol., 2001, 29, 264-273.

118 E. Parente, C. Brienza, A. Ricciardi and G. Addario, J. Ind. Microbiol. Biotechnol., 1997, 18, 62-67.

119 T. Kobayashi, K. Yamazaki, D. K. Bagenda and Y. Kawai, Bull. Fish. Sci., 2010, 60, 5-12.

120 L. Johnsen, G. Fimland, V. Eijsink and J. Nissen-Meyer, Appl. Environ. Microbiol., 2000, 66, 4798-4802.

121 L. A. Purwanto, D. Ibrahim and H. Sudrajat, World J. Chem., 2009, 4, 34-38.

122 Y. M. Lee, J. S. Kim and W. J. Kim, Food Sci. Biotechnol., 2012, 21, 653-659.

123 A. S. Motta and A. Brandelli, Appl. Microbiol. Biotechnol., 2003, 2-3, 163-167.

124 M. P. Castro, N. Z. Palavecino, C. Herman, O. A. Garro and C. A. Campos, Meat Sci, 2011, 4, 321-329.

125 F. Leroy and L. De Vuyst, Appl. Environ. Microbiol., 2003, 69, 1093-1099.

126 E. Tome, V. L. Pereira, C. I. Lopes, P. A. Gibbs and P. C. Teixeira, Food Control, 2008, 5, 535-543.

127 K. Adinarayana and P. Ellaiah, Int J Pharm Pharm Sci, 2002, 3, 281-287.

128 S. Puri, Q. K. Beg and R. Gupta, Curr. Microbiol., 2002, 4, 286-290.

129 S. L. Liew, A. B. Ariff, A. R. Raha and Y. W. Ho, Int J Food Microbiol, 2005, 2, 137-142.
130 S. K. Das and A. K. Sabat, Electron. J. Geotech. Eng., 2008, 13, 1-13.

131 R. Nicolai and R. Dekker, Qual Technol Quan Manag, 2009, 1-28.

132 S. Usmiati and T. Marwati, Indonesian Journal of Agricultural Science, 2009, 2, 82-92.

133 S. Youssefi, Z. Emam-Djomeh and S. M. Mousavi, Drying Technol., 2009, 7-8, 910-917.

134 W. L. Guo, Y. B. Zhang, J. H. Lu, L. Y. Jiang, L. R. Teng, Y. Wang and Y. C. Liang, Afr. J. Biotechnol., 2010, 38, 6264-6272.

135 J. S. Tan, R. N. Ramanan, T. C. Ling, M. Shuhaimi and A. B. Ariff, Minerva Biotecnologica, 2011, 3, 63.

136 W. Peng, J. Zhong, J. Yang, Y. Ren, T. Xu, S. Xiao, J. Zhou and H. Tan, Microb. Cell Fact., 2014, 13, 54.

137 A. T. Caldeira, J. M. Arteiro, J. C. Roseiro, J. Neves and H. Vicente, Bioresour. Technol., 2011, 102, 1496-1502.

138 K. M. Desai, S. A. Survase, P. S. Saudagar, S. S. Lele and R. S. Singhal, Biochem. Eng. J., 2008, 3, 266-273.

139 P. Wilaipun, T. Zendo, M. Sangjindavong, S. Nitisinprasert, V. Leelawatcharamas, J. Nakayama and K. Sonomoto, Kasetsart J., 2002, 36, 268-277.

140 S. D. Todorov and L. M. T. Dicks, J. Basic Microbiol., 2004, 44, 305-316.

141 S. D. Todorov and L. M. T. Dicks, World J. Microbiol. Biotechnol., 2005, 21, 1585-1590.

142 N. Arbsuwan, J. Apiraksakorn, P. Laopaiboon and V. Leelavatcharamas, Presented in part at the 2nd international conference on fermentation technology for value added agricultural products, Khon Kaen, Thailand, 2007.

143 V. Mollendorff and J. Wilhelm, Master of Science, Stellenbosch University, 2008.

144 M. Papagianni and S. Anastasiadou, Microb. Cell Fact., 2009, 8, 3.

145 E. O. Khay, L. M. P. Castro, P. F. Bernardez, N. S. Senhaji, M. Idaomar and J. Abrini, Afr. J. Biotechnol., 2012, 11, 659-665.

146 P. Desjardins, J. Meghrous and C. Lacroix, Int. Dairy J., 2001, 11, 943-951.

147 N. P. Guerra and L. P. Castro, Biotechnol. Appl. Biochem., 2002, 36, 119-125.

148 N. P. Guerra and L. Pastrana, Lett. Appl. Microbiol., 2003, 37, 51-55.

149 J. A. Vázquez, M. P. Gonzalez and M. A. Murado, Electron. J. Environ., Agric. Food Chem., 2004c, 3, 648-657.

150 F. Crispie, D. Twomey, J. Flynn, C. Hill, P. Ross and W. Meaney, J. Dairy Sci., 2005, 72, 159-167.

151 C. Liu, Y. Liu and S. Chen, Appl. Biochem. Biotechnol., 2005, 121-124, 475-483.

152 G. Enan and A. A. A. Amri, J. Food, Agric. Environ., 2006, 4, 85-88.

153 Y. Furuta, N. Maruoka, A. Nakamura, T. Omori and K. Sonomoto, J. Biosci. Bioeng., 2008, 106, 393-397.

154 S. Y. Gonzalez-Toledo, J. Dominguez-Dominguez, B. E. Garcia-Almendarez, L. A. Prado-Barragán and C. Regalado-González, J. Food Sci., 2010, 75, 347-353. 
155 S. D. Todorov and L. M. T. Dicks, Food Technol. Biotechnol., 2005, 43, 165-173.

156 J. Tomás, M. Silvina, E. Bru and M. E. Nader-Macias, J. Chem. Technol. Biotechnol., 2010, 85, 91-99.

157 A. Aguilar-Galvez, S. Guillermo, R. Dubois-Dauphin, D. Campos and P. Thonart, Ann. Microbiol., 2011, 61, 955964.

158 B. J. Ramachandran, V. Srivathsan, J. Sivakami, M. Harish, D. J. Ravi kumar and M. kumar, J. Acad. Ind. Res., 2012, 1, 306-309.

159 M. M. Patil, K. V. Ramana and A. S. Bawa, J. Food Process. Preserv., 2013, 37, 179-187.

160 H. A. Nel, R. Bauer, E. J. Vandamme and L. M. T. Dicks, J. Appl. Microbiol., 2001, 91, 1131-1138.

161 N. Xiraphi, M. Georgalaki, G. Van Driessche, B. Devreese, J. Van Beeumen, E. Tsakalidou, J. Metaxopoulos and E. H. Drosinos, Antonie van Leeuwenhoek, 2006, 89, 19-26.

162 S. D. Todorov and L. M. T. Dicks, Enzyme Microb. Technol., 2005, 36, 318-326.

163 S. D. Todorov and L. M. T. Dicks, Process Biochem., 2006, 41, 11-19.

164 G. M. Vignolo, M. N. de Kairuz, A. A. P. de Ruiz Holgado and G. Oliver, J. Appl. Microbiol., 2008, 78, 5-10.

165 J. W. von Mollendorff, S. D. Todorov and L. M. T. Dicks, Trakia Journal of Sciences, 2009, 7, 22-23.

166 V. Trinetta, M. Rollini and M. Manzoni, Process Biochem., 2008, 43, 1275-1280.

167 S. D. Todorov, R. P. S. Oliveirab and M. Vaz-Velhoc, Chem. Eng., 2010, 27, 283-288.

168 N. Chanprasert and P. Gasaluck, Asian Journal of Food \& Agro-industry, 2011, 4, 54-64.

169 H. Mahrous, A. Mohamed, M. A. El-Mongy, A. I. El-Batal and H. A. Hamza, Food Nutr., 2013, 4, 342-356.
170 M. Calderón-Santoyo, P. G. Mendoza-Garcia, M. A. GarciaAlvarado and B. I. Escudero-Abarca, J. Ind. Microbiol. Biotechnol., 2001, 26, 191-195.

171 M. A. Yusuf and T. H. A. Tengku Abdul Hamid, IOSR J. Pharm., 2012, 2, 49-59.

172 D. Dussault, K. D. Vu and M. Lacroix, Probiotics Antimicrob. Proteins, 2016, 8, 170-175.

173 E. N. Danial, S. H. M. Al-Zahrani and Z. A. M. Al-Mahmoudi, J. Appl. Pharm. Sci., 2016, 6, 020-027.

174 P. Mall, B. K. Mohanty, D. B. Patankar, R. Mody and R. Tunga, Braz. Arch. Biol. Technol., 2010, 53, 203-209.

175 S. Abbasiliasi, R. N. Ramanan, T. A. T. Ibrahim, S. Mustafa, R. Mohamad, H. H. M. Daud and A. B. Ariff, Biotechnol. Biotechnol. Equip., 2011, 25, 2652-2657.

176 S. Abbasiliasi, Doctor of Philosophy, Universiti Putra Malaysia, 2014.

177 N. Chinachoti, H. Matsusaki, K. Sonomoto and A. Ishizaki, J. Fac. Agric., Hokkaido Univ., 1997, 42, 171-181.

178 C. Li, J. Bai, W. Li, Z. Cai and F. Ouyang, Biotechnol. Prog., 2001, 2, 366-368.

179 S. K. Tiwari and S. Srivastava, Food Biotechnol., 2008, 22, 6477.

180 M. Kumar and S. Srivastava, Trakia Journal of Sciences, 2010, 8, 12-21.

181 P. Kanmani, R. S. Kumar, N. Yuvaraj, K. A. Paari, V. Pattukumar and V. Arul, Prep. Biochem. Biotechnol., 2011, 41, 40-52.

182 A. Arokiyamary and P. K. Sivakumaar, Int. J. Biomed. Res., 2011, 568-574.

183 H.-Y. Choi, J.-S. Kim and W.-J. Kim, Korean J. Food Sci. Technol., 2011, 31, 176-182.

184 M. Kumar, A. K. Jain, M. Ghosh and A. Ganguli, Biotechnol. Bioprocess Eng., 2012, 17, 606-616. 